\title{
Christianity, Idolatry, and the Question of Jewish Figural Painting in the Middle Ages
}

\author{
By Katrin Kogman-Appel
}

In 1233 a certain R. Joseph bar Moses of Würzburg commissioned an illuminated copy of Rashi's Bible commentary, now in Munich. ${ }^{1}$ After the text was finished, the task of illuminating was put into the hands of a Christian painter, apparently a man named Heinrich, who kept a lay workshop in Würzburg (Fig. 1). ${ }^{2}$ Three years later a giant Bible, now in Milan, was commissioned perhaps by the same patron, but not necessarily in the same city (Fig. 2). ${ }^{3}$ It, too, was illuminated; this time, however, it cannot be excluded that the paintings were made by Jewish artists. ${ }^{4}$ Both manuscripts are richly decorated with narrative scenes involving

Shorter versions of this paper were presented at the annual meeting of the Medieval Academy of America, Toronto, April 2007, at a session organized by Adam Cohen, Linda Safran, and Jill Caskey, "Rethinking the Canonical Texts and Topographies of Medieval Art," and at a symposium in memory of Kurt Schubert at the University of Vienna, October 2007. Research on this paper was part of a project on thirteenth-century Hebrew prayer books supported by a grant from the Israeli Science Foundation (no. 756/03). I am indebted to Chaim Harvey Hames and Ruth Iskin for commenting on earlier drafts of this paper and to Ephraim Shoham-Steiner for always being ready patiently to discuss texts, images, and thoughts.

' Munich, Bayerische Staatsbibliothek, MS heb. 5. See Elisabeth Klemm, Die illuminierten Handschriften des 13. Jabrbunderts deutscher Herkunft in der Bayerischen Staatsbibliothek, Katalog der illuminierten Handschriften der Bayerischen Staatsbibliothek in München 4 (Wiesbaden, 1998), pp. 198-202.

${ }^{2}$ For considerations of this kind of Jewish-Christian collaboration see Eva Frojmovic, "Jewish Scribes and Christian Illuminators-Interstitial Encounter and Cultural Negotiation" (forthcoming); and Sarit Shalev-Eyni, Jewus among Christians: A Hebrew Workshop of Illuminated Manuscripts in the Lake Constance Region (forthcoming). I am grateful to both Eva Frojmovic, University of Leeds, and Sarit Shalev-Eyni, Hebrew University of Jerusalem, for sharing with me their as-yet-unpublished work.

${ }^{3}$ Milan, Biblioteca Ambrosiana, MS B 30-32 inf. See Bezalel Narkiss, Hebrew Illumninated Manuscripts [in Hebrew] (Jerusalem, 1984), pp. 116-17, pl. 25; this edition is a revised and expanded Hebrew version of the original English (Jerusalem, 1969). The colophon of the Milan Bible mentions R. Joseph bar Moses as originating from "Olmena," interpreted as Ulm in Swabia by Narkiss, Hebrew Illuminated Manuscripts, p. 117; Frojmovic, "Jewish Scribes"; and Kurt and Ursula Schubert, Jïdische Buchkunnst, Buchkunst im Wandel der Zeiten 3, 2 vols. (Graz, 1983-92), 1:85-86. Although this is the only place for which a Jewish community at this time is certain, no other Hebrew source refers to Ulm as Olmena; the name might thus also indicate Olmen (Ulmen) in the district of Kochem, Olm near Mainz, or Ulm near Renchen; see I. Elbogen, A. Freimann, and H. Tykocinsky, Germania Judaica, 1: Von den ältesten Zeiten bis 1238 (Tübingen, 1963), pp. 253-54.

${ }^{4}$ Whereas the Munich manuscript of Rashi clearly represents the well-documented style of the Würzburg workshop, the Milan Bible cannot be associated with any of the known workshop styles. Moreover, it displays the specifically Jewish feature of human figures with animal heads or hidden faces, a puzzling phenomenon widely discussed but not yet definitively explained. This may indicate that the Bible was decorated by Jews. On the animal heads and other distortions of the human face see Schubert,

Speculum 84 (2009) 


\section{Aus rechtlichen Gründen steht diese Abbildung nicht im Open Access zur Verfügung}

Fig. 1. Munich, Bayerische Staatsbibliothek, MS heb. 5/, fol. 47v (detail). R. Solomon ben Isaac, Commentary on the Bible, Würzburg, 1233. (All illustrations reproduced by permission.)

Buchkunst, 1:72 73; Bezalel Narkiss, "On the Zoocephalic Phenomenon in Mediaeval Ashkenazi Manuscripts," in Norms and Variations in Art: Essays in Honour of Moshe Barasch (Jerusalem, 1983), pp. 214 36; and Thérèse and Mendel Metzger, "Méir ben Barukh de Rothembourg et la question des images chez les juifs au moyen âge," Aschkenas: Zeitschrift für Geschichte und Kultur der Juden 1 (1994), 59-60. Jewish texts on figural painting are concerned with the special status of the face, and it is possible that they had an influence on the phenomenon. See, for example, Babylonian Talmud, Avodab zarab 42b; for an English version see The Babylonian Talmud, ed. I. Epstein, 6 parts and index, in 35 vols. (London, 1935 52), 4/7:211-12. See also R. Meir ben Barukh of Rothenburg, 
Aus rechtlichen Gründen steht diese Abbildung nicht im Open Access zur Verfügung

Fig. 2. Milan, Biblioteca Ambrosiana, MS B 30-32 inf. vol 1 fol 1r: Bible, southern Germany, 1236 
human figures. ${ }^{5}$ In the following decades it became more and more customary for wealthy Jews of Germany and northern France to have their.Bibles, prayer books, and other texts adorned with figural miniatures. Yet there is no evidence that during the Middle Ages human figures were painted in any form in a Jewish context before the 1230s. A few textual references from the twelfth century indicate wall paintings and stained-glass windows in synagogues with images of animals and dragons, but none have survived. ${ }^{6}$ Some decades after the first illuminated books made their appearance, the most outstanding authority on religious law of his time, R. Meir ben Barukh of Rothenburg (d. 1293), was asked his opinion of this phenomenon. R. Meir was worried, as his reply shows, but not for reasons of religious law; his concern was that images in painted books would distract believers from their pious concentration during prayer: ${ }^{7}$

In Spain the earliest figural paintings in illuminated Hebrew manuscripts, such as British Library, MS Or: 2737, were made in Castile around the year $1290 .^{8} \mathrm{In}$

She elot uteshuvot maharam bar barukh 496, ed. F. Galinsky and S. L. Flecker (Lvov, 1860), p. 52; for a facsimile of this edition see She elot uteshuvot maharam bar barukh merotenburg, 2 (Jerusalem, 1986). The responsum is by R. Meir, but it quotes R. Ephraim of Regensburg (1110-75). However, neither these texts nor indeed the various theories about the phenomenon of animal heads explain why it is restricted to southern Germany and why it ceased to appear in the middle of the fourteenth century. In the Munich manuscript of Rashi the faces were originally painted but were erased at some later stage (according to Frojmovic, "Jewish Scribes," this was done right away and at the demand of the Jewish patron).

${ }^{s}$ For some details of the nature of these and other early Ashkenazi manuscrips, their style, and iconography see, for example, Narkiss, Hebrew Illuminated Manuscripts, pp. 42-56; and Gabrielle Sed-Rajna, Le mahzor enluminé: Les voies de formation d'un programme iconographique (Leiden, 1983). Two Ashkenazi prayer books from this period have been published in facsimile, and their commentary volumes include information about their iconographic programs; see The Worms Mahzor: The Jewish National and University Library in Jerusalem, MS beb. 4o 781/1, ed. Malachi Beit-Arié (Vaduz, 1986); and Machsor Lipsiae: 68 Faksimile Tafeln der mittelalterlichen bebräischen illuminierten Handschrift aus dem Bestand det Universitätsbibliothek Leipzig, ed. Elias Katz (Vaduz, 1964). More recently see also Shalev-Eyni, Jetus arinong' Christians.

${ }^{6} \mathrm{R}$. Meir ben Barukh of Rothenburg, She elot uteshuvot, ed. Galinsky and Flecker, p. 52. See also a thirteenth-century text referring to a no-longer-extant responsum by R. Elyakim ben Joseph of Mainz (b. c. 1170) in R. Isaac ben Moses of Vienna, Or zarua, 4 (Jerusalem, 1976), Avodab zarab 203, p. 55; for an English translation of this section see Vivian B. Mann, ed., Jewish Texts on the Visual Arts (New York, 2000), pp. 74-75.

${ }^{7}$ R. Meir ben Barukh of Rothenburg, Sefer sha are teshuvot maharam bar barukh zal 97, ed. Moshe A. Blach (Berlin, 1891), p. 134. For an English translation see Mann, Jewish Texts, pp. 110-11. This text does not explicitly mention human figures; however, as illuminated Hebrew books with figural depictions had become quite common at the time it was composed, it can plausibly be assumed that R. Meir was aware that they include images of human figures. As is well known (see, for example, Mann, Jewish Texts), this statement recalls similar concerns issued by Bernard of Clairvaux, Apologia ad Guillelmum Abbatem 29, cited in Conrad Rudolph, The "Things of Greater Importance": Bernard of Clairvaux's Apologia and the Medieval Attitude toward Art (Philadelphia, 1990), p. 283, and for a discussion of the phrase in Rudolph's title see pp. 104-24. Whether these thoughts appearing in parallel in Christian and Jewish texts are an outcome of exchange or mere coincidence is yet to be explored but goes beyond the scope of this study.

${ }^{8}$ On MS Or. 2737, a Haggadah, see Bezalel Narkiss, Aliza Cohen-Mushlin, and Anat Tcherikover, Hebrew Illuminated Manuscripts in the British Isles: A Catalogue Raisonné, 1: The Spanish and Portuguese Manuscripts (Oxford, 1982), no. 9, pp. 45-51. This Haggadah reflects some stylistic features of manuscripts produced for King Alfonso X, the Learned, of Castile (d. 1284). On the assumption 
the first half of the fourteenth century a tradition of illuminated Haggadot appears to have flourished in the various regions of the Crown of Aragon, to which a group of about ten examples from the years between 1320 and 1350 still bears witness. ${ }^{9}$ Among the earliest examples is the so-called Golden Haggadah, now in the British Library (Fig. 3).

In both Germany and Spain this art was nourished to various degrees by Christian visual culture. Style and technique owed much to Christian manuscript painting; in terms of imagery as well, Jewish art did not develop in isolation. Whereas Ashkenazic imagery depended less on Christian pictorial sources, the art of the Sephardic Haggadot exhibits various ways of interaction with Christian art. Making extensive use of Christian pictorial sources, ${ }^{10}$ the authors of these Jewish cycles $^{11}$ developed sophisticated strategies to translate their models into a specific Jewish idiom. Being quite familiar with the particulars of Christian typological interpretation of the Old Testament, they filtered out elements of particular Christological meaning and altered the iconography accordingly. ${ }^{12}$ They represented pictorial versions of Israelite biblical history based on the principles of rabbinic exegesis, which was revived in Sephardic scholarship of the thirteenth century in reaction to the Maimonidean controversy over philosophy. ${ }^{13}$ Like Christian artists and patrons, they were thus well aware of the potential of religious art as an exegetical tool.

In the 1230s Jewish figural art was thus a revolutionary novelty. Jews had last commissioned a work of art with human figures seven hundred years before, when the synagogue of Beth Alpha in the Beth Shean valley was decorated during the reign of Emperor Justin I (Fig. 4) ${ }^{14}$ and the synagogue of $\mathrm{Na}^{\prime}$ aran near Jericho

that Jewish art tends to be archaic Narkiss, Cohen-Mushlin, and Tcherikover date the Haggadah to the early fourteenth century. For an alternative view about Or. 2737 see Katrin Kogman-Appel, Jewish Book Art between Islam and Christianity: The Decoration of Hebrew Bibles in Medieval Spain, trans. Judith Davidson, The Medieval and Early Modern Iberian World 19 (Leiden, 2004), chap. 3.

9 See Narkiss, Cohen-Mushlin, and Tcherikover, Hebrew Illuminated Manuscripts, pp. 57-100; and Katrin Kogman-Appel, Illuminated Haggadot from Medieval Spain: Biblical Imagery and the Passover Holiday (University Park, Pa., 2006).

${ }^{10}$ Kogman-Appel, Illuminated Haggadot, pt. 1.

"I refer to the creators of these cycles as "authors" or "designers" in the broadest possible sense. Scholars still struggle with the question of whether most Hebrew illuminated manuscripts were decorated by Jewish artists or in Christian workshops. On the one hand we know several names of Jewish artists mentioned in colophons; see Yael Zirlin, "Celui qui se cache derrière l'image: Colophons des enlumineurs dans les manuscripts hébraïques," Revue des études juives 155 (1996), 33-53; and Kogman-Appel, Book Art, chap. 4. On the other hand there is plentiful evidence that certain manuscripts may have been commissioned in Christian workshops. The Munich manuscript of Rashi, mentioned above (p. 73), is an example; see also Shalev-Eyni, Jews among Christians, who describes the collaboration of a Jewish scribe with a Christian painting workshop. In any event, most cases demonstrate that the contents of the images are specifically Jewish and were, as far as I can judge, authored or designed by Jewish scholars, patrons, and scribes who must have been responsible for the layout of the decorations and its planning.

${ }^{12}$ Katrin Koginan-Appel, "Coping with Christian Pictorial Sources: What Did Jewish Miniaturists Not Paint?" Speculum 75 (2000), 816-58.

${ }^{13}$ For more background, with reference to literature on the Maimonidean controversy, see KogmanAppel, Illuminated Haggadot, chap. 7.

${ }^{14}$ Eliezer L. Sukenik, The Ancient Synagogue of Beth Alpha (Jerusalem, 1932). 
Aus rechtlichen Gründen steht diese Abbildung nicht im Open Access zur Verfügung

Fig. 3. London, British Library, MS Add. 27210, fol. 9r.

Golden Haggadah, Barcelona, c. 1320. 
Aus rechtlichen Gründen steht diese Abbildung nicht im Open Access zur Verfügung

Fig. 4. Synagogue of Beth Alpha. Mosaic, c. 518-27. 


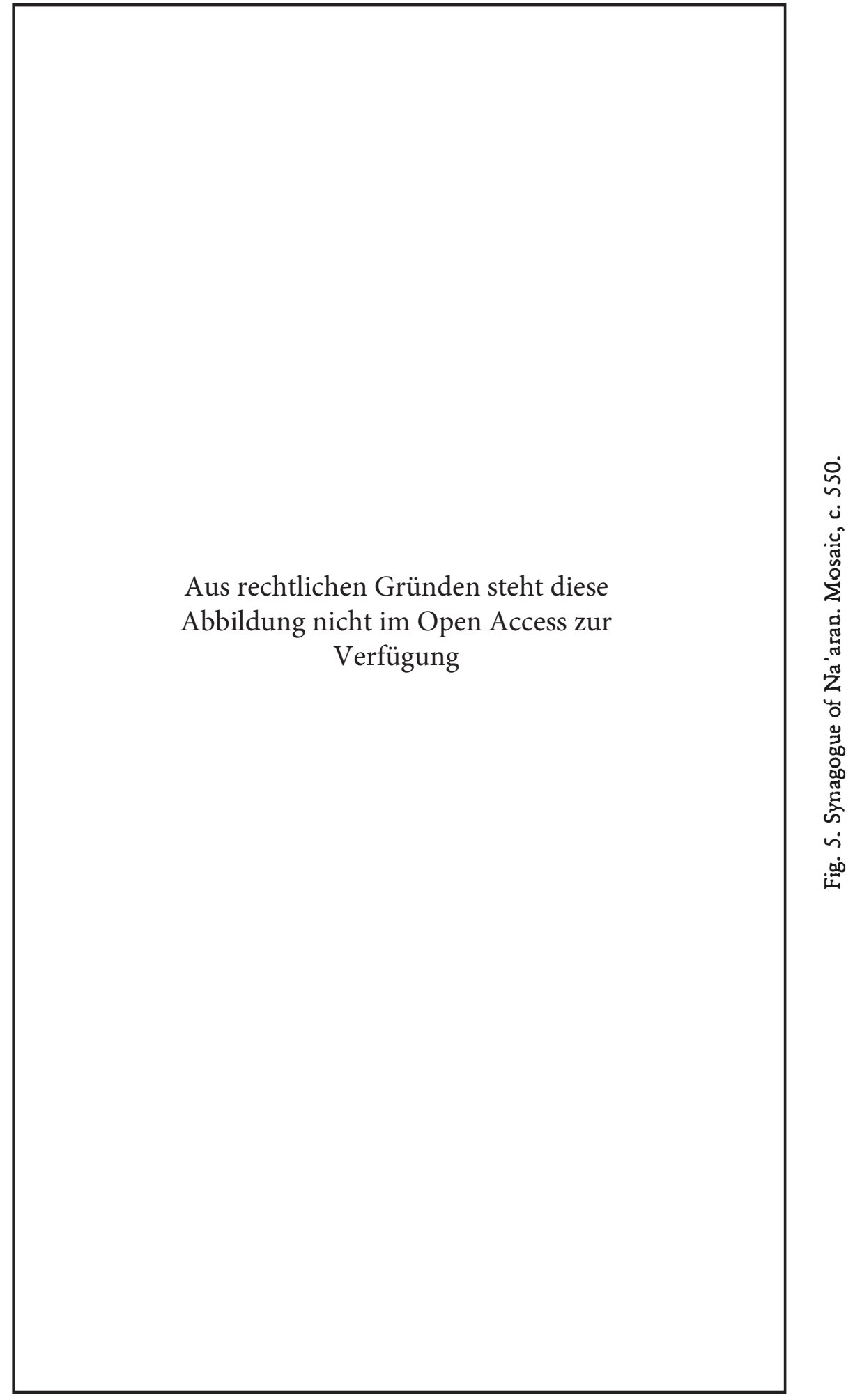


was embellished around 550 (Fig. 5). The question of figural art in a Jewish context has frequently been raised, with most scholarly discussions concentrating on the issue of the Second Commandment (Exodus 20.4), the biblical prohibition of idolatry. Elsewhere I have shown that the phenomenon of Jewish figural art is not necessarily only a matter of the religious law, the Halakhah, but rather that it depends on varying dynamics of acculturation with the non-Jewish environment. ${ }^{15}$ From the halakhic point of view, the biblical prohibition applied only to threedimensional objects, which could be taken for idols. ${ }^{16}$ Images, however-in particular two-dimensional ones-produced for the mere sake of decoration did not, according to most talmudic authorities, present a contravention. ${ }^{17}$ Often these authorities treat the issue of human figures separately; however, most sources agree that painted human figures do not constitute a halakhic problem. ${ }^{18}$

Numerous types of interactions with Roman or early Christian culture are reflected in late-antique synagogal art; likewise, Jews within the Islamic realm adopted the aniconic characteristics of Islamic religious art, notwithstanding the explicit opinion of Maimonides (d. 1204) that two-dimensional images of human

${ }^{15}$ Katrin Kogman-Appel, "Jewish Art and Cultural Exchange in Late Antiquity and in Medieval Europe," in Cultural Encounters in the Mediterranean, ed. Alan Chong (forthcoming).

${ }^{16}$ For a thorough discussion of the source material regarding various issues of three-dimensional representation in the context of pagan culture see Gerald J. Blidstein, "Rabbinic Legislation on Idolatry: Tractate Abodah Zarah, Chapter I" [in Hebrew] (Ph.D. dissertation, Yeshiva University, 1968), chap. 6.

${ }^{17}$ See, for example, Rabban Gamaliel II's discussion of the statue of Aphrodite in a public bath in Mishnah, Avodah zarab 3.4 (Babylonian Talmud, Avodab zarah 44b, ed. Epstein, 4/7:220-21), discussed at length in Blidstein, "Rabbinic Legislation," chap. 7; or the discussion about seals with convex or concave images in the Jerusalem Talmud, Avodab zarab 3.1 (for an English version see Jacob Neusner, ed., The Talmud of the Land of Israel: An Acadenic Commentary to the Second, Third, and Fourth Divisions, South Florida Academic Commentary Series 136 [Atlanta, 1998], p. 92), and, for a discussion, see Blidstein, "Rabbinic Legislation," pp. 224-36). The picture that arises from the reading of talmudic sources, however, is not entirely homogeneous, and occasionally voices calling for restrictions can be heard; see, for example, a commentary to Exodus 20.4 in Mekbilta derabbi Yishmael, Pischa 6, ed. and trans. Jacob Z. Lauterbach, 2 (Philadelphia, 1933), p. 241, an explicit prohibition of every kind of image, especially three-dimensional ones, but also mirror images, implying that the prohibition covers also two-dimensional images. This saying is attributed to R. Akiva, a contemporary of Rabban Gamaliel II, but it seems to contradict the latter's more liberal attitude. On this text see Blidstein, "Rabbinic Legislation," pp. 210-17, who emphasizes that this is not a legislative text but an exegetical one and who believes that its relevance in the judgment of rabbinic laws about artistic representation was limited. Blidstein also emphasizes that this passage in the Mekbilta cannot be judged as paradigmatic. Blidstein's point of departure is not an elucidation of artistic finding but rather the question of preservation of Jewish identity within gentile environments; therefore he is concerned primarily with the source material from the mishnaic and the talmudic periods, which he does not bring into correlation with the archaeological evidence. Numerous other works examine the textual evidence against the background of artistic findings; one of the most comprehensive studies, discussing most of the relevant sources, is Ephraim E. Urbach, "The Rabbinical Laws of Idolatry in the Second and Third Centuries in the Light of Archeological and Historical Facts," Israel Exploration Journal 9 (1959), 149-65 and 229-45; for a recent summary of the issue see Lee I. Levine, The Ancient Synagogue: The First Thousand Years (New Haven, Conn., 2000), pp. 451-58.

${ }^{18}$ For more information on the issue of human figures"see Blidstein, "Rabbinic Legislation," pp. 23640. Restrictions regarding human forms have to do with the fact that they might hint at the appearance of God, who had created man in his own image (Genesis 1.26). In any event Blidstein concludes that human figures for the mere sake of decoration are allowed. 
Aus rechtlichen Gründen steht diese Abbildung nicht im Open Access zur Verfügung

Fig. 6. St. Petersburg, National Library of Russia, Firkovich Cöllection, MS II B 17, fragment.

Egypt (?), 929.

figures do not contradict Jewish law. ${ }^{19}$ The earliest dated example of an illuminated Hebrew manuscript is a Pentateuch fragment in St. Petersburg, produced in Egypt (?) in 929 (Fig. 6). It contains various types of ornamental decoration and two nonfigurative, rather abstract representations of the Temple. ${ }^{20}$ In short, whether Jews created and used art and what form of art they produced in these periods

${ }^{19}$ Mishne Torah, Sefer Hamada, Hilkhot avodat kokhavim 3.10, ed. Joseph Kappah (Jerusalem, 1984), p. 399. For an English version see Mann, Jewish Texts, pp. 23-24.

${ }^{20}$ For more information on manuscripts from the Islamic realm see Bezalel Narkiss, Illuminations from Hebrew Bibles of Leningrad (Jerusalem, 1990); and Kogman-Appel, Book Art, chap. 2. On the iconography of medieval Jewish images of the Temple see Elisabeth Revel-Neher, Le témoignage de l'absence: Les objets du sanctuaire à Byzance et dans l'art juif du XIe au XVe siècle (Paris, 1998). 
and places depended on the dynamics of cultural interactions with their nonJewish environment.

In the medieval Christian world acculturation functioned differently. At some point during the second half of the sixth century, Jews ceased to commission, create, or use figural art. In most Christian environments Jews seem not to have produced much of a visual culture at all. During the early-medieval period Jews lived in Christian environments in Byzantium and southern Italy, and beginning in the ninth century they settled in the German lands and subsequently in northern France and in England. Various kinds of economic and cultural interactions developed during this period. The twelfth century, for example, was significant in that it was a period of cultural flourishing for both Jews and Christians, and recent scholarship has pointed out a variety of interactions and mutual influences. ${ }^{21}$ Various signs of acculturation can be observed, but the visual arts, and especially figural imagery, were excluded from it. The theoretical halakhic background remained the same as in late antiquity. ${ }^{22}$ It was, for example, never fully adapted to the medieval circumstances of Byzantine icon worship. In theory the distinction between three-dimensional idols and two-dimensional decorative images remained valid, and nowhere was it written that two-dimensional images are prohibited. Some other kind of barrier must have existed during these centuries that prevented the Jews from developing figural art.

During the early Middle Ages Jewish-Christian relationships were determined by Augustine's theology of the Jewish people as a legitimate witness to the truth of the Christian faith. Toward the later Middle Ages those relationships steadily deteriorated for various reasons and in a variety of circumstances, subject to debate among historians. Agobard of Lyons (778-840) developed the ideal of a pure Christian society, in which the legitimate place of the Jews began to be questioned. The persecutions during the First Crusade opened another page, and Christian attitudes to the Jews began to involve physical violence. These developments reached a peak during the thirteenth century.3.

Strangely enough, it was during the 1230 s, in the midst of this very period of worsening relationships, that the barrier that had excluded Jewish figural art from other dynamics of acculturation was lifted. At first sight, this period of religious hostility seems the least likely to lead to new forms of cultural interactions. But

\footnotetext{
${ }^{21}$ For a good summary of this question see Ivan G. Marcus, "The Dynamics of Jewish Renaissance and Renewal in the Twelfth Century," in Jews and Christians in Twelfth-Century Europe, ed. Michael A. Signer and John Van Engen, Notre Dame Conferences in Medieval Studies 10 (Notre Dame, Ind., 2001), pp. 9-27.

${ }^{22}$ Kalman P. Bland, The Artless Jew: Medieval and Modern Affirmations and Denials of the Visual (Princeton, N.J., 2000), p. 152.

${ }^{23}$ Literature on anti-Jewish attitudes in the twelfth and the thirteenth century is abundant, and only a selection can be given here. For a general survey see Kenneth R. Stow, Alienated Minority: The Jewvs of Medieval Latin Europe (Cambridge, Mass., 1992); for attitudes to Jews in Christian texts see Jeremy Cohen, Living Letters of the Law: Ideas of the Jetv in Medieval Christianity (Berkeley, Calif., 1999); for the role of the mendicant orders in Jewish history since the thirteenth century see Jeremy Cohen, The Friars and the Jewus: The Evolution of Medieval Anti-Judaism (Ithaca, N.Y., 1982); for the question of whether the First Crusade was a watershed in Jewish history see Robert Chazan, European Jewury and the First Crusade (Berkeley, Calif., 1987), and idem, Medieval Stereotypes and Modern Antisemitism (Berkeley, Calif., 1997).
} 
in the midst of years of persecution and destruction Jews began to show an interest in figural art. They went so far as to commission illuminations in Christian workshops, adopted the styles and techniques of Christian book art, and coped inventively with Christian pictorial sources. Moreover, Jewish figural art appeared first in southern Germany, a region that suffered even more than others from antiJewish activities. In the following decades it was adopted in Capetian France, an environment likewise hardly designed to encourage new forms of cultural exchange. ${ }^{24}$ In Spain, on the other hand, where the situation of the Jews deteriorated only later, during the fourteenth century, and where Jewish-Christian relationships were marked by certain levels of what scholars occasionally define as conviven$\mathrm{cia}^{25}$ the development of figural art and the adoption of Christian styles and imagery lagged behind. The present study will attempt to analyze the circumstances of what thus seems a cultural paradox.

The development of Jewish figural art after a gap of seven hundred years has not received any sustained attention in previous scholarship. Numerous stimuli most likely led to such a dramatic change in Jewish culture. Occasionally the appearance of Jewish book art has been linked to the development-of urban Christian lay workshops in the thirteenth century; early-medieval Christian manuscripts were produced exclusively in monastic workshops and were therefore believed to have been inaccessible to Jews. Only in secular workshops-a by-product of urban development-could Jews acquire painting techniques, purchase or borrow model books, and commission manuscript decoration. ${ }^{26}$ Those assumptions, important as they are, leave several questions open. Hebrew texts, to be discussed below in more detail, occasionally mention images in Jewish contexts already in the twelfth century. As far as the texts can be understood, the images seem not to have included human figures. However, they imply that Jewish patrons were already familiar with Christian art, practices, motifs, and techniques prior to the appearance of urban manuscript workshops $s_{\Perp}$ and took an interest in artistic expression. Furthermore, the acquaintance with Christian artistic practices through urban workshops could have led to the development of a Jewish art other than the figural. Theoretically, if the human figure would have been an issue, Jewish art could have remained within the boundaries of aniconic design. Moreover, there is evidence that Jews traded with Christians liturgical objects of various kinds and received them as collateral; ${ }^{27}$ those objects could have included books. Ideas and

\footnotetext{
${ }^{24}$ William Chester Jordan, The French Monarchy and the Jews: From Philip Augustus to the Last Capetians (Philadelphia, 1989).

${ }^{25}$ On the somewhat problematic notion of convivencia in late-medieval Spain see Thomas F. Glick, "Introduction," in Convivencia: Jewus, Muslims and Christians in Medieval Spain, ed. Vivian B. Mann, Thomas F. Glick, and Jerrilyn D. Dodds (New York, 1992), pp. 7-14; and Benjamin R. Gampel, "Does Medieval Navarrese Jewry Salvage Our Notion of Convivencia?" in In Iberia and Beyond: Hispanic Jews between Cultures. Proceedings of a Sympositun to Mark the 500th Anniversary of the Expulsion of Spanish Jewry, ed. Bernard Dov Cooperman (Newark, Del., 1998), pp. 97-122.

${ }^{26}$ Schubert, Buchkunst, 1:123; Gabrielle Sed-Rajna et al., L'art juif, L'Art et les Grandes Civilisations 25 (Paris, 1995); Mann, Jetvish Texts, p. 109.

${ }^{27}$ The use of Christian liturgical objects as collateral was discussed and prohibited in R. Moses of Coucy, Sefer mitsvot gadol, 2: Mitsvot lo ta aseh, hilkhot avodah zarah (Jerusalem, 1961), p. 10a (a facsimile of the Venice 1547 edition). In 1220 a rabbinical synod in Mainz prohibited the purchase
} 
the necessary technical knowledge could have come from contacts with such objects, if desired. Christian manuscripts were produced in monastic as well as royal contexts, and manuscripts for the latter were often used and commissioned by laymen. If Jews had a wish to express their religious feelings and beliefs visually, they could quite readily have found ways and means to acquire the necessary technical skills. ${ }^{28}$

There may have been other causes that led to the development of Jewish figural art. Changes in the socioeconomic structure of the Jewish communities may have had something to do with the developments of a new Jewish art. Developments in the relationship between rabbinic leadership and patronage may also have had an impact on Jewish culture's adapting dynamically to changing conditions in the environment. Such developments undoubtedly could have stimulated the production of figural Jewish book art in some way or other. The particulars of the dynamics of Jewish society that may have led to this kind of artistic expression certainly deserve treatment in future investigations. The current study takes a different point of view and seeks to explain the conditions that made possible the development of Jewish figural art. It examines what first hindered figural art and what changes occurred that made figural art possible. Whatever the circumstances that could have stimulated representational art, it began to develop suddenly within a culture that had hitherto associated figural artistic expression with religious practices that had negative effects on the maintenance of its own identity. The reason for the change cannot have had anything to do with improved relationships between the two religions or a consequently stronger acculturation; nor did it necessarily have much to do with halakhic interpretations of the Second Commandment. Rather, it will be suggested here that the explanation lies in changing Jewish perceptions of Christianity. In what follows textual evidence from various contexts and cultural backgrounds will shed light on the dynamics of those perceptions and will be brought into correlation with the beginnings of Jewish figural art in Germany during the 1230s and in Spain around 1300.

of liturgical objects; see Friedrich Lotter, "Hostienfrevelvorwurf und Blutwunderfälschung bei den Judenverfolgungen von 1298 ('Rintfleisch') und 1336-1338 ('Armleder')," in Fälschungen im Mittelalter, MGH Schriften 33/5 (Hannover, 1988), pp. 573-74, n. 167 with further references. Earlier, in the tenth century, R. Gershom ben Judah Me'or Hagolah had already permitted trade with such objects: Tshuvot rabbenu Gershom me or hagolah 21, ed. Solomon Eidelberg (New York, 1956), pp. 75-77; see Ivan G. Marcus, "A Jewish-Christian Symbiosis: The Culture of Early Ashkenaz," in Cultures of the Jews: A New History, ed. David Biale (New York, 2002), p. 462. See also Moshe Halbertal, Between Torah and Philosophy: Rabbi Menahem Hame iri and the Maimonidean Halakhists in Provence [in Hebrew] (Jerusalem, 2000), p. 81; on the context of Hame iri's concept of religious tolerance see below, pp. 102-5.

${ }^{28}$ We know very little about lay scriptoria of twelfth- and thirteenth-century Europe; some examples are discussed by Michael Gullick, "The Illuminator of Gloucester," English Manuscript Studies, 110017005 (1995), 209-13; and Patricia D. Stirnemann, "Nouvelles pratiques d'enluminure au temps de Philippe Auguste," in La France de Philippe Auguste: Le temps des mutations, ed. Robert-Henri Bautier, Colloques Internationaux du Centre national de la recherche scientifique 602 (Paris, 1982), pp. 955-80. According to Jonathan J. G. Alexander, Medieval Illuminator's and Their Methods of Work (New Haven, Conn., 1992), chap. 5, the twelfth and thirteenth centuries mark a transition period during which lay illuminators began to dominate over monastic artists. 


\section{IDOLATRY AND CHRISTIANITY}

In late antiquity contacts between Jews and gentiles-pagan gentiles in the original context-were regulated by the Tractate of Idolatry, literally, "foreign worship" (avodah zarah) of the Babylonian Talmud. A set of laws was developed by Jewish scholars between the second and the fifth century, based on the prohibition of foreign, non-Jewish cult. Its aim was a clear definition of the Jews in a gentile environment in order to guarantee the preservation of Jewish identity. ${ }^{29}$ The Jews of late-antique Babylonia lived in large, strong, and economically independent communities within a multicultural environment of mostly pagan, idolatrous background. ${ }^{30}$ Christians played only a minor role in the original developments of these laws.

In antiquity the term "foreign worship" was understood unambiguously as idolatry. It was used as a synonym for other terms, such as "idol worship" (avodat elilim) or "worship of celestial bodies and constellations" (avodat kokbavim umazalot). Prior to Christianity and Islam, all non-Jewish cultures were placed in the same category of foreign, idolatrous worshipers. ${ }^{31}$ An exception was made for the descendants of Noah, who were given 7 laws, including the prohibition of idol worship. ${ }^{32}$ Like the Israelites, who on Mount Sinai took upon themselves the observance not only of the 7 laws but the entire set of 613 biblical laws, the Noahides did not belong to the category of pagan idolaters. Toward the end of the late-antique period and during the Middle Ages, however, Jews had to face the question whether the two other monotheistic religions should be defined as idolatrous or could be considered Noahide. With regard to Islam there was not much of a dilemma, as Jews did not have any serious doubts that Muslims were monotheists. ${ }^{33}$ With regard to Christianity the answer was not unambiguous. Theoretically, there were three options: Christians are Noahides, who observe the 7 laws; Christians are Noahides but neglect"to observe the 7 laws; or Christians are idolaters. Two issues left Jews in doubt whether Christianity could and should be considered a monotheistic religion. First, the Trinitarian dogma and the belief in the incarnation of God could not be reconciled with monotheism. ${ }^{34}$ Second, the developing Christian cult of images caused further doubt that Christians could be referred to as Noahides.

\footnotetext{
29 On several aspects of this tractate see Blidstein, "Rabbinic Legislation."

${ }^{30}$ On Babylonian Jewry see Yeshayahu Gafni, Babylonian Jews in the Talmudic Period [in Hebrew] (Jerusalem, 1986).

${ }^{31}$ For a definition and a discussion of different concepts of idolatry see Moshe Halbertal and Avishai Margalit, Idolatry (Cambridge, Mass., 1992), esp. the introduction, pp. 1-8.

${ }^{32}$ Genesis 9, and the rabbinic interpretation of the laws in the Babylonian Talnud, Sanhedrin 56a. For an English version see Epstein, 4/5:381-82. See also Aaron Lichtenstein, The Seven Laws of Noah (New York, 1981); and David Novak, The Image of the Non-Jew in Judaism: An Historical and Constructive Study of the Noabide Laws, Toronto Studies in Theology 14 (New York, 1983).

${ }^{33}$ For a medieval source see, for example, the anonymous collection Sefer kol bo 96, ed. Israel J. Vidavsky (Jerusalem, 1997), p. 381.

${ }^{34}$ For a thorough discussion of Jewish polemics against the Trinity and the Incarnation see Daniel J. Lasker, Jewish Philosophical Polemics against Christianity in the Middle Ages (New York, 1977), pp. 45-134.
} 
Early Christendom did not develop any religious art before c. 200. As Paul C. Finney argues, the want of Christian visual expression prior to that date does not necessarily have anything to do with iconophobic attitudes but rather with a whole range of political, social, and economic factors. ${ }^{35}$ Early Christianity grew out of the Jewish religion, and the attitude of early Christians to the image and to figural art may quite naturally have been similar to that of the Jews, and thus ambivalent. During the first two centuries C.E., Jews also did not engage in figural art, even though the rabbis did not necessarily object to it. ${ }^{36}$ Art was also associated with Greco-Roman culture, and it was therefore occasionally a target of polemics among the earliest church fathers. ${ }^{37}$ Christian art began to develop in the late second century and clearly preferred two-dimensional forms. Recently Kalman Bland compared the preference of Eastern Christendom for flat icons to the acceptance of two-dimensional art in synagogues and argued that both phenomena should be seen in correlation and in reaction to Roman veneration of threedimensional idols. ${ }^{38}$ From the fifth century on, signs of Christian image worship increased. At first it faced opposition from the church authorities, but it became a firmly established and accepted cult around the last decades of the sixth century. ${ }^{39}$

It seems reasonable to assume that after a period of doubt as to how to perceive Christianity, Jews began, as a result of the development of icon worship, to consider Christianity an idolatrous religion. As Charles Barber has shown, this can be indirectly inferred from sixth- and seventh-century adversus Judaeos texts addressing Jewish critiques of the Christian use of religious images, such as that by Leontios of Neapolis, bishop of Cyprus during the early seventh century. ${ }^{40}$ Jewish figural art fell into disuse around the same time, with Jews employing only aniconic modes of decoration after c. 550 for almost seven centuries. Even some cases of iconoclasm occurred, as the example of the synagogue at $\mathrm{Na}$ aran implies (Fig. 5). ${ }^{41}$

\footnotetext{
${ }^{35}$ Paul Corby Finney, The Invisible God: The Earliest Christians on Art (Oxford, 1994).

${ }^{36}$ For a recent discussion of late-antique Jewish iconophobia see Lee I. Levine, "Figural Art in Ancient Judaisn," Ars Judaica 1 (2005), 9-26.

${ }^{37}$ Finney, Invisible God, pp. 15-68.

${ }^{38}$ Kalman Bland, "Icons vs. Sculptures in Christian Practice and Jewish Law," Jewish Studies Quar-
} terly 11 (2004), 201-14. Bland does not discuss the sudden interruption of Jewish figural art in the sixth century or its sudden reoccurrence in the thirteenth.

${ }^{39}$ On the development of the cult of images see Ernst Kitzinger, "The Cult of Images in the Age before Iconoclasm," Dumbarton Oaks Papers 8 (1954), 85-150.

${ }^{40}$ Charles Barber, "The Truth in Painting: Iconoclasm and Identity in Early-Medieval Art," Speculum 72 (1997), 1019-36, at p. 1023. The relevant texts are listed in n. 15.

11 The mid-sixth-century mosaic floor of $\mathrm{Na}$ aran, which presented the traditional imagery of Temple implements, the zodiac, and a biblical scene (Daniel in the lions' den), was destroyed at some later stage. Since the nonfigural religious symbols and the Hebrew inscriptions remained intact, most scholars tend to agree that this was the doing of Jewish iconoclasts. Whether the destruction occurred in reaction to Christian icon worship, under the influence of Islamic iconophobia and iconoclasm, or that of Byzantine iconoclasm is not entirely clear. For a summary of the discussion see Barber, "The Truth in Painting," p. 1022, n. 11, and p. 1023, n. 12; see also David Amit, "Iconoclasm in Ancient Synagogues in Israel" [in Hebrew], in Proceedings of the Eleventh World Congress of Jewish Studies B/1 (Jerusalem, 1994), pp. 9-16, who makes a point of the selectivity of the erasures and argues that they were done by Jews while the synagogues were still functioning. For more recent remarks on this phenomenon see Steven Fine, "Iconoclasm and the Art of Late Antique Palestinian Synagogues," in 
It is difficult to decipher the Jewish textual evidence from this period, which is scattered in talmudic literature. Numerous rabbinic texts refer to idolatry or to images (tselamim), but in most cases it cannot be said with certainty whether they mean pagan images or are applying the terminology developed in a pagan context to Christianity; the majority of these texts predate the sixth century. Whereas there is no doubt that in the Middle Ages, at least in central Europe, the term tselem refers to the cross or other Christian images, no such certainty exists with regard to the late-antique evidence. A late-third-century saying by the Palestinian Amoraic $R$. Tanhum ben Hanilay about the three youths in the furnace with a reference to the veneration of the $t$ selem ${ }^{42}$ could theoretically have hinted at a Christian practice; given the date, however, and the fact that the saying appears in the Babylonian Talmud, a pagan context seems more likely. The midrash Deuteronomy rabbab, on the other hand, discusses the sin of King Manasseh (2 Kings 21), which is interpreted as an image (tselem) of the tetramorph. Since Deuteronomy rabbab is dated between the fifth and eighth centuries, this text may have been influenced by the adoption of the tetramorph in Christian iconography and by the symbols of the Evangelists. ${ }^{43}$ In Midrash tanbuma, finally, for which a similar time frame is suggested, the kingdoms governed by the image (tselem) are mentioned, and the fact that "image" appears in the singular, and not "images" in a polytheistic sense, may indicate that the word refers to the cross. ${ }^{44}$ Given the date, it can reasonably be assumed that the reference is to Christianity.

That meaning for tselem became more and more evident during the Middle Ages, when the veneration of images became commonly associated with Chris-

\footnotetext{
From Dura to Sepphoris: Studies in Jewish Art and Society in Late Antiquity, ed. Lee I. Levine and Zeev Weiss, Journal of Roman Archaeology Supplementary Series 40 (Portsmouth, R.I., 2000), pp. 183-95; and Levine, "Figural Art," pp. 23-25. Numerous Christian sources also speak of iconoclastic aggression on the part of infidels and Jews; Bianca Kühnel, however, rejects the notion of Jewish iconoclasm and argues that iconoclasm is a phenomenon that depends on the existence of a doctrine of art, to be opposed; see "Jewish Art and 'Iconoclasm': 'The Case of Sepphoris," in Representation in Religion: Studies in Honour of.Moșhe Barasch, ed. Jan Assmann and Albert I. Baumgarten, Studies in the History of Religions 89 (Leiden, 2001), pp. 161-80. For more details on Jewish iconoclasm, and a suggestion that it occurred in reaction to the Christian cult of images, see Kitzinger, "Cult of Images," p. 130, esp. n. 204; and Michael Avi-Yonah, Oriental Art in Roman Palestine, Studi Semitici 5 (Rome, 1961), p. 42. Barber, "The Truth in Painting," in principle accepts Kitzinger's notion and proposes that, apart from the aversion to the new Christian cult of images, Jewish.iconoclasm may also have been a reaction to anti-Jewish attitudes. According to Barber; Jewish objections to the cult of images, and the resulting coming to grips with issues of Jewish identity, caused the Jews to abandon figural art and to go as far as to destroy images. Bland ("Icons vs. Sculptures," p. 213) looks at icon worship from a different angle and argues that herein lies one of several differences between the Jewish and the Christian attitudes to art, although the two are basically to be linked as reactions to Roman idolatrous art.

${ }^{42}$ Babylonian Talmud, Sanhedrin 93a. For an English version see Epstein, 4/6:622.

${ }^{43}$ Midrash devarim rabbah 2.20, in Makhon hamidrash hamevu ar (Jerusalem, 1983), p. 73. For an English version see H. Freedman and Maurice Simon, eds., The Midrash rabbah, 5 vols. (London, 1977), 4:47. On the dating of Deuteronomy rabbah see H. L. Strack und G. Stemberger, Introduction to the Talmud and Midrash, trans. Markus Bockmuehl (Minneapolis, 1992), p. 335; see also Midrash tanhuma, bebukotai 5, ed. Samuel Buber, 2 (New York, 1946), pp. 110-11; and Eliyabu zutta 9, ed. Meir Ish-Shalom (Jerusalem, 1960), p. 188.

${ }^{44}$ Midrash tanbuma, trumab 6, ed. Buber, p. 92. On the date of Midrash tanbuma see Strack and Stemberger, Introduction, pp. 332-33.
} 
tians. ${ }^{45}$ Tselem became a common code word for "crucifix" or "cross." 46 There are several interesting points in medieval Jewish references to Christian images. First of all, the texts normally no longer distinguish so sharply between three- and two-dimensional objects, as if the authors were aware that Christian veneration could be directed to both types of image; the term tselem was therefore applied to both forms of representation. On the one hand, rabbinic literature, like the Bible, refers to the statue of Nebuchadnezar in Daniel 3.1 as a tselem; ${ }^{47}$ on the other, it remarks that Haman embroidered a tselem on his garment. ${ }^{48}$ In the medieval tradition both Nebuchadnezar and Haman are viewed as prototypes of Christian figures. In dealings with the pagan world the distinction between the venerated three-dimensional object, the idol, and the merely decorative twodimensional painting was crucial in determining the Halakhah. For Jews who lived in the Islamic world this distinction continued to play a determining role..$^{49} \mathrm{In}$ texts that refer to the Christian cult, however, the distinction between the three- and the twó-dimensional no longer functioned as a clear dividing line as in late antiquity. In theoretical halakhic discussions of a merely academic nature and for the sake of basic halakhic definition, the late-antique rule remained valid. ${ }^{50}$ But when it comes to specific discussions of the tselem, and to actual Christian works of art, the texts do not make it clear whether the tselem is two- or three-dimensional. It thus appears that the Jews were well aware that Christian image worship was unlike pagan idolatry in that it could be directed also to paintings, that is, icons. ${ }^{51}$ Halakhists did not, however, go as far as to change the basic halakhic rules with regard to figural representation.

\footnotetext{
${ }^{45}$ Medieval anti-Jewish texts present a picture of Jews attacking Christian image worship, similar to that arising from their late-antique precedents; see Eric Lawee, "Graven Images, Astromagical Cherubs, and Mosaic Miracles: A Fifteenth-Century Curial-Rabbinic Exchange," Speculum 81 (2006), 767.

${ }^{16}$ Bland provides important and detailed discussions of some of the medieval Jewish sources that refer to Christian images in terms of objects of idolatry: R. Samuel ben Meir (twelfth century) on images and crosses on altars; R. Petahiah of Regensburg's (twelfth-century) description of a church near Rachel's tomb; and Rashi's interpretation of the Golden Calf from a polemical point of view; see Artless Jew, pp. 115-23, with references to the primary sources.

${ }^{47}$ Midrash bereshit rabbah 68.12, ed. Yehuda Theodor and Hanoch Albeck (Jerusalem, 1996), p. 789. For an English version see Freedman and Simon, Midrash rabbah, 2:628.

${ }^{48}$ Midrash Esther rabbah (II) 7.5 on Esther 3.1-2 (this passage is not included in some of the traditional editions; see, for example, that of S. Dunsky [Montreal, 1962], p. 153); Midrash megillat Esther; Esther 3.1-2, in Sammlung kleiner Midraschim, ed. C. M. Horowitz, 1 (Berlin, 1882), p. 64; Midrash megillat Esther; Esther 2.5, in Beth hamidrash, ed. A. Jellinek, 1 (Leipzig, 1923), p. 23. For more details about Haman in Jewish tradition and art see Katrin Kogman-Appel, "The Tree of Death and the Tree of Life: The Hanging of Haman in Medieval Jewish Manuscript Painting," in Between the Picture and the Word: Manuscript Studies from the Index of Christian Art, ed. Colum Hourihane, Index of Christian Art, Occasional Papers, 8 (Princeton, N.J., 2005), pp. 187-208.

${ }^{49}$ For Maimonides' views see above, pp. 81-82.

${ }^{50}$ For examples see R. Moses of Coucy, Sefer mitsvot gadol (above, n. 27), p. 9a; and R. Asher ben Yehiel, Tosafot harosh, Avodah zarab 3, ed. R. Shraga Hakohen Welman (New York, 1978), p. 21.

s1 Two texts frequently cited with reference to the attitude of medieval rabbinical authorities to art are the ones mentioned above (nn. 4 and 6) by R. Ephraim of Regensburg and R. Elyakim of Mainz; from both it becomes clear that the distinction between three- and two-dimensional was no longer as crucial as it was in the talmudic era. For a detailed discussion of these texts see Metzger, "Méir ben Baroukh de Rothembourg."
} 
It was thus most probably the development of the Christian worship of icons that led to the abandonment of figural art among Jews in the sixth century: since Jews considered the Christian use of works of art for religious purposes idolatrous, they did not adopt the figural arts as a means of religious expression during the early Middle Ages, despite various other types of cultural interactions with the Christian environment. When Jewish figurative art appeared for the first time in the 1230s, Jewish-Christian relations were, as previously noted, at their worst. With the halakhic distinction between two- and three-dimensional objects unchanged, and the levels of mutual hostility steadily increasing, only a change in the Jewish perception of Christianity as an idolatrous religion could have led to this quite significant move in Jewish culture. ${ }^{52}$

\section{AshKeNAZ: . Gentiles of Our Time Do Not Adhere to Idolatry}

Textual evidence indicates that during the late twelfth and the thirteenth centuries a slight shift occurred that began to undermine the firm Jewish perception of Christianity as an idolatrous religion. Several rabbinic statements, all linked in some way to the question of "foreign cult" and contacts with gentiles, point in this direction. Some of them appear in relation to or as comments on the talmudic tractate Avodab zarah. Others were formulated within rabbinic responses to queries put by members of various Jewish communities. These responses form the bulk of what is referred to in scholarship as responsa literature and constitute an important source for the understanding of medieval rabbinic law. The texts mentioned in the following paragraphs are part of a larger corpus of halakhic discussions, all concerned with questions of how to maintain Jewish identity within gentile societies.

Already Rashi (R. Solomon ben Isaac, d. 1105) in the eleventh century had begun to rethink the Jewish view. of Christianity and idolatry. He had become aware that in his own, western European environment-he lived in TroyesChristian religious practice did not exactly correspond to idolatry as the Talmud referred to it. In one of his responsa he declared, "Gentiles of our time are not skilled in the ways of idolatry, ... and on those grounds the Jews are now used to take debts from the gentiles in the form of wine." ${ }^{33}$ Elsewhere Rashi observed

52 In general, idolatry refers in the medieval perception to the religion of the Other or to heretical beliefs. From the Christian point of view pagans, heretics, Jews, and Muslims were idolatrous. Michael Camille has exhaustively studied the iconography of this perception in The Gotbic Idol: Ideology and Image-Making in Medieval Art (Cambridge, Eng., 1989), esp. chap. 3 dealing with the Jews as idolaters. It would be interesting to examine to what degree the Jews were familiar with and reacted to this perception and how it shaped their own views, but that is beyond the scope of this study. For further insights on the Jews as idolaters see Sara Lipton, Images of Intolerance: The Representation of Jews and Judaism in the Bible moralisée (Berkeley, Calif., 1999), pp. 40-42.

${ }^{5}$ R. Solomon ben Isaac (Rashi), Tshuvot Rasbi 327, ed. Israel S. Elfenbein, 2 (Jerusalem, 1967), p. 337. If not indicated otherwise, translations of rabbinic texts are my own. Published English versions have occasionally been modified for the sake of accuracy. The notion that there are gentiles who are not really idol worshipers appears as early as the Talmud, which occasionally mentions gentiles outside the country, who are not counted among common idol worshipers; Babylonian Talmud, Hullin 13b 
that "the gentiles in the areas where we live do not offer libations of wine for idolatry." " 4 Wine produced and traded by gentiles was considered to be suspect of the pagan practice of libation (nesekb). In Babylonia the practice was very common, and it was forbidden to Jews to drink such wine or to trade in it. Those restrictions continued to exist also in Europe, but Rashi observed that they might no longer be relevant. The argument reappeared in the second half of the twelfth century, when R. Isaac of Dampierre (d. 1198) similarly asserted that "contemporary gentiles do not know idolatry." "ss Theoretically and according to the halakhic method of Samuel, a talmudic sage of the late-antique period, one may therefore be permitted to trade with wine that had been touched by such gentiles. R. Isaac, however, rejected this possibility in the most vehement terms, since, as Haim Soloveichik argues, the issue of wine-unlike other aspects of JewishChristian contacts-was a particularly delicate one..$^{56}$

About two generations after Rashi, R. Eliezer ben Nathan, another Ashkenazi authority (d. 1170), shed further light on the question. More explicit in his judgment, he made a distinction between East and West. In the context of the assertion that the gentiles of his time were not skilled in idolatry, he elaborated on and referred explicitly to Byzantine icon worship: "In Russia and the lands of Greece they are certainly skilled [in idolatry], as they put [objects of] idolatry on all their gates, on all their doors, in their houses, and on the walls of their houses." ${ }^{57}$ Jews of the twelfth century were thus aware of the cultural differences between Latin and Greek Christendom regarding icon worship and other uses of art. Moreover, for them the Christians of the West were lax in their observance of image worship,

cites R. Hiyya bar Abba, who says, on behalf of R. Yohanan (bar Nappaha), that gentiles abroad (meaning the Golan area or the Trachonitis in southern Syria) are not worshipers of "celestial bodies and constellations" (or "idolatry" according to some textual versions) but follow the custom of their fathers. Both R. Hiyya bar Abba and R. Yohanan lived in the Land of Israel during the first half of the third century, and it is not quite certain whether they are referring to Romans or to Christians, the latter not yet forming a dominant culture in any area. R. Yohanan's saying was later quoted by $R$. Gershom Me'or Hagolah (d. 1028), Tshuvot 21, ed. Eidelberg, pp. 75-77, regarding the question whether Jews are allowed to conduct business negotiations with gentiles during the latter's holidays or even, as the original law determines, on the three days that precede the actual holiday (see below, pp. 92-93). R. Gershom, aware of the economic necessities of his fellow Jews, eased some of the restrictions and concluded his discussion by a reference to R. Yohanan's statement: "in times of [economic] pressure we can refer to R. Yohanan, that gentiles (nokbrim) outside the Land of Israel are not idolaters." See Israel Ta-Shma, "Their Holidays': A Chapter in the Development of Medieval Halakba" [in Hebrew], Tarbitz 47 (1977-78), 199-200; see also more recently idem, Halakbah, Custom, and Reality in Ashkenaz, 1000-1350 [in Hebrew] (Jerusalem, 1996), chap. 14. This is the first time that the view that Christians are not entirely to be regarded as idolaters enters the halakhic discourse. Unlike later statements on this matter, R. Gershom does not make it a major argument but only further support for his approach. Halbertal and Margalit (Idolatry [above, n. 31], p. 211) argue that $R$. Gershom was certainly concerned that the Jews "maintain Christianity as an idolatrous religion, especially in view of the Jews' continual struggle against it."

${ }^{54}$ Haym Soloveitchik, Principles and Pressures: Jewish Trade in Gentile Wine in the Middle Ages [in Hebrew] (Tel Aviv, 2003), p. 51, n. 28, with further similar statements.

ss Cited in R. Judah of Paris, Tosafot Rabbenu Yehudab bar Yitshak miparis, avodah zarah 57b, ed. Judah Hakohen Blau (New York, 1979), p. 275.

s6 Soloveitchik, Gentile Wine, p. 104.

$s 7$ R. Eliezer ben Nathan, Sefer even ba'ezer bu sefer Raban 291, ed. Shlomo Z. Ehrenreich (Jerusalem, 1974), p. 125a; Ta-Shma, "Their Holidays," p. 203. 
whereas those of Russia and the Greek lands were more faithful. What is implied here is not necessarily that Christians were no longer considered idolaters. Rather; the Jews had become aware that something had changed in the Christian cult of images. From the Jewish point of view there was no reason to look more deeply into the particulars of the cultural difference between Byzantium and the West. For Jews of the eleventh and twelfth centuries Christians were idolaters, but Byzantine Christian's were so-to-speak faithful idolaters, whereas western Christians had become negligent. No real change had yet occurred in the Jewish perception of Christianity per se as idolatrous.

The context of Rashi's observation and the resulting considerations were of an economic nature. Unlike the Babylonian Jews of late antiquity, European Jews during the early Middle Ages lived in small communities, which could not maintain themselves economically and depended in various ways on interactions with the Christian environment. The laws developed in the talmudic Tractate of Idolatry with the aim of regulating relationships with gentiles therefore had to be adapted from the Babylonian situation of large, self-sufficient Jewish settlements to small communities that depended on the hosting society. Moreover, as scholars of Jewish history have shown, actual practices of conducting business relationships appear to have been affected by the changed circumstances, and the law had to be adapted accordingly. The law restricted contacts with gentiles, but in the economic and social reality of medieval Europe that restriction could no longer be maintained to the same degree. This process was described years ago by Jacob Katz. ${ }^{58}$ On the basis of the observation that contemporary gentiles were not "skilled in idolatry," certain modifications of the original laws could be introduced in order to facilitate the contacts with Christians that were necessary to develop economic relationships, in fact, to legitimize actual practice. In both realms, the Babylonian and the Christian, the purpose of these laws was to maintain Jewish identity and to prevent the Jewish minority from assimilating so thoroughly to the gentile environment as to disappear. On the one hand, economic contacts with Christians were a necessity; on the other, Christians, much more than pagans in Babylonia, had a theological concern to encourage, and later to force, the Jews to convert. The threat of conversion and loss of identity created a certain level of aversion to Christianity, which naturally grew when Christian pressure increased.

Katz argued that the Jewish perception of Christians as idolaters or nonidolaters had a determining impact on halakhic considerations in a fluid economic situation. His theory will be revisited here from the point of view of visual culture; the texts he used will be reexamined together with further and different textual evidence and with consideration of the results of more recent scholarship. I shall propose that the medieval process of halakhic adaptation determined economic developments, as others have already argued, but, further, that the nature of argumentation adopted in this process provided the conditions for the sudden appearance of Jewish figural art in the thirteenth century.

Rashi's observation that contemporary gentiles were not skilled (beki in) in idolatry led ultimately to a gradual, even if slight, change in the Jewish perception

${ }^{58}$ Jacob Katz, Exclusiveness and Tolerance: Studies in Jewish-Gentile Relations in Medieval and Modern Times, Scripta Judaica 3 (London, 1961), pt. 2. 
of Christians. Eventually Rashi's statement with its somewhat belittling undertone gave way to a somewhat different understanding. By the thirteenth century we find this argumentation fairly often, but with a variation. Contemporary gentiles, European Jews began to observe, were no longer adhering (adukin) to idolatry. That Rashi's statement was indeed belittling and implied that, in his opinion, the Christians were lax in the observance of their own religious practice was argued by Israel Ta-Shma, who asserted that the comment refers to Christians as both unskilled in and not adhering to idolatry. I would argue that the fact that in the later sources a different wording was consistently preferred seems to indicate that an additional shift had occurred in the Jewish view regarding Christians. ${ }^{59}$ The transition from "not skilled" to "not adhering" is a first sign of a shift in perception. As a matter of fact, Rashi himself once used the terminology that later would become more frequent. ${ }^{60}$ In the thirteenth century the observation that contemporary gentiles do not adhere to idolatry appears more and more often in the sources, and it had a determining influence on various halakhic dealings with respect to Jewish-Christian economic relationships.

Throughout the thirteenth century a similar argument emerged in Germany, France, and Spain. An example is a text by R. Isaac ben Moses of Vienna (c. 1180-c. 1250), the author of the halakhic work Or zarua, who discussed business negotiations during gentile holidays and defined the Christians of his time as gentiles "among whom we live and who do not adhere to idolatry." ${ }^{61}$ The issue is discussed similarly in the Sefer kol bo, a collection of mostly halakhic texts of various-often Ashkenazi-backgrounds from the same period, attributed to R. Aaron Hokohen of Lunel:

Three days [before their holiday] it is forbidden to negotiate with them [the gentiles], to have trade with them, to bargain with them, to lend to them or borrow from them, to pay them back or to receive a payment from them. And Samuel said: in the Diaspora it is forbidden only on the holiday itself. And Rabbenu Perets wrote in his laws: in our period one may negotiate with the gentiles even on their holiday; and the saying that it is forbidden to negotiate with them on the three days [preceding their holiday] refers to those gentiles who lived there and went forth to give thanks; ${ }^{62}$ but the gentiles outside the Land of Israel do not adhere to idolatry. ... ${ }^{63}$

\footnotetext{
${ }^{59}$ Ta-Shma, "Their Holidays," p. 202.

${ }^{60}$ Rashi on Babylonian Talmud, Avodah zarab 7b (Rashi's commentary is printed in all traditional editions of the Babylonian Talmud).

${ }^{61}$ R. Isaac ben Moses of Vienna, Or zarua, 4 (above, n. 6), Avodah zarab 1, p. 30. R. Isaac claims to rely on R. Samuel bar Meir (d. 1174), Rashi's son-in-law, whose text is no longer extant. It is therefore not clear whether the transition from beki 'in, as used normally in Rashi, to adukin, as in $\mathrm{Or}$ zarua, occurred in R. Samuel's text or only later in R. Isaac's text.

62 This refers to pagan practices in antiquity, when after successful business transactions, pagans went forth and thanked their idols.

${ }^{63}$ Sefer kol bo 97, ed. Vidavsky, p. 393. Some Ashkenazic scholars of the thirteenth century demanded a stricter observance of the restrictions regarding business negotiations and trade during gentile holidays. According to Ta-Shma, "Their Holidays," pp. 205-6, this was due either to pietistic influence or to the fact that Ashkenazic Jews of the thirteenth century no longer supported themselves by trade.
} 
The same distinction was made in France by R. Moses ben Jacob of Coucy in his Sefer mitsvot gadol, composed shortly after 1240 . He used almost the same wording and referred to the gentiles of the Diaspora as gentiles "who are not really idolaters." ${ }^{64} \mathrm{He}$ also remarked that if one knows that a certain gentile does not adhere to idolatry, contacts for the sake of business negotiations could be eased. ${ }^{65}$

A few decades later; an interesting statement was made by R. Yeruham ben Meshullam, another southern French scholar, born in 1290, who left for Toledo in the early fourteenth century:

My teacher R. Abraham ben Asmael wrote: with regard to [utensils of] gentiles of this time who do not worship the sun or the moon, or the image of a dragon, utensils with such images are permitted for [their economic] benefit, but it is forbidden to keep them.... It is forbidden to make an image of the sun, and if one finds an image of a woman with her son in her arms, or the image of a cross with a man hung on it-they are forbidden. But if they possibly belong to those gentiles who do not adhere to idolatry and all they do with these images on the utensils is to enjoy their beauty, they are permitted for [their economic] benefit, but it is forbidden to keep them . . . because of the suspicion that they might be protruding [i.e., three-dimensional]. ${ }^{66}$

This text, although dated later than the period crucial for understanding the beginnings of figural art, is quite revealing: the observation that there are gentiles who do not adhere to idolatry was, according to R. Yeruham, directly related to the way a Christian work of art could and should be handled by Jews.

Eventually this line of thought and the arguments resulting from it were to have an influence also on Jewish apologetics against claims of anti-Christian hostility. This can be learned from the Hebrew protocol of the Paris Talmud trial in 1240 . During the first half of the thirteenth century Christian theologians began to develop an increasing interest in Jewish postbiblical law, the Talmud. Judaism as defined in Augustinian witness theology was biblical Judaism. It dealt with Jews who accepted the Old Testament as a holy book but misunderstood its Christian viewpoint. It was only during the later Middle Agès that Christians began to be aware that Jewish life was regulated by the Talnaud no less than by the Bible. This awareness led to various suspicions that contemporary Jews-as opposed to biblical Jews-had developed anti-Christian attitudes believed to be rooted in the Talmud, especially in those parts of it that deal with idolatry and contacts with gentiles. ${ }^{67}$

The suspicion that Jewish law was hostile to Christians was not entirely new. According to Robert Chazan, a turning point in the development of anti-Jewish stereotypes occurred around the middle of the twelfth century with Bernard of Clairvaux and Peter the Venerable. ${ }^{68}$ As Yvonne Friedmann points out, Peter the

\footnotetext{
${ }^{64}$ R. Moses of Coucy, Sefer mitsvot gadol, p. 10a.

65 Ibid.

${ }^{66} \mathrm{R}$. Yeruham ben Meshullam, Toldot adam vehava 17.4 (Venice, 1553; repr. Jerusalem, n.d.), p. $157 \mathrm{~b}$. A similar statement appears ibid. 17.1, p. 150a. It is interesting to note that notwithstanding the keen observation of the nuances of Christian art, when it comes to the basic legal aspect of the discussion, the old distinction between the two- and the three-dimensional image is determinative.

${ }^{67}$ The literature is abundant; the standard works are Ch. Merchavia, The Church versus Talmudic and Midrashic Literature (500-1248) [in Hebrew] (Jerusalem, 1970); Cohen, The Friars and the Jews; and idem, Living Letters (both works cited above, n. 23), pt. 4.

${ }^{68}$ Chazan, Medieval Stereotypes (above, n. 23), pp. 41-54.
} 
Venerable, although briefly and without relying on specific textual evidence, asserted that the Talmud was anti-Christian, and he did so between 1144 and 1147, the same years when the first blood libels occurred in Norwich and in Würzburg. ${ }^{69}$ During the late twelfth and the early thirteenth centuries Christian theologians began to search the Talmud systematically, with the assistance of baptized Jews. The talmudic Tractate of Idolatry, which contains several hostile expressions against idolaters and non-Jewish practices, was one of the main targets, and Christian theologians developed the suspicion that the talmudic laws against idolatry and their hostile implications referred to Christian society. In consequence, any hostile statements regarding pagan idol worship were believed to be aimed at Christians.

This process reached a peak in 1236, when Nicholas Donin, a baptized Jew from La Rochelle in France, who had turned vehemently against his former religion, submitted to Pope Gregory IX a list of talmudic statements alleged to be of an anti-Christian nature. ${ }^{70}$ This step ultimately led to the public trial of the Talmud and the burning of rabbinic texts in $1242 . .^{11}$ Donin's accusation circled around three major themes: the assertion that the Talmud, although apparently illogical and full of contradictions, is, in the eyes of the Jews, more important than the Bible; the accusation that the Talmud contains blasphemies against God, Jesus, and his mother; ${ }^{72}$ and the suspicion that the Talmud contains numerous antiChristian expressions and guides to hostile conduct. Gregory reacted to Donin's list three years later, in 1239, with an explicit request to search the Talmud for anti-Christian expressions. ${ }^{73}$ Although his request was addressed to various political authorities, with the exception of Emperor Frederick II, who was in deep conflict with the pope over crusading matters, it was carried out only in France, and it was in Paris that the Talmud was put on trial.

Donin himself voiced the accusations against the Talmud, whose defense was put into the hands of R. Yehiel ben Joseph of Paris (d. after 1260). The trial is

\footnotetext{
${ }^{69}$ Yvonne Friedman, "Anti-Talmudic Invective from Peter the Venerable to Nicolas Donin (11441244)," in Le brûlement du Talmud à Paris, 1242-1244, ed. Gilbert Dahan and Elie Nicolas (Paris, 1999), pp. 171-89.

${ }^{70}$ For more on Donin see Jordan, The French Monarchy and the Jews (above, n. 24), pp. 137-41. For an English translation of the accusations see Cohen, Living Letters, p. 321.

${ }^{71}$ Historians debate the immediate causes of Donin's actions, how exactly the trial proceeded, and its precise character; discussion of these controversies is beyond the scope of this paper. For a recent summary see, for example, Judah Galinsky, "'The Talmud Trial' in 1240 in Paris: 'The Dispute of R. Yehiel' and 'Sefer Hanitsvot' of R. Moses of Coucy" [in Hebrew], Shnaton hamishpat ha 'ivri 22 (2001-3), 45-48. Galinsky lists most of the relevant literature on the trial; see esp. nn. 2-4.

72 For a discussion of blasphemies believed to be directed against Mary and the role they played in the context of the trial see William Chester Jordan, "Marian Devotion and the Talmud Trial of 1240," in Religionsgespräche im Mittelalter, ed. Bernard Lewis and Friedrich Niewöhner, Wolfenbütteler Mittelalter-Studien 4 (Wiesbaden, 1992), pp. 61-76.

${ }^{73}$ For references to Christian sources, including Donin's thirty-nine accusations and Gregory's letter; see Isidore Loeb, "La controverse de 1240 sur le Talmud," Revue des études juives 2 (1881), 252-70, and 3 (1881), 39-55; and Solomon Grayzel, The Church and the Jetus in the XIIIth Century, rev. ed. (New York, 1966), pp. 240-42. Those discussions are based on Extractiones de Talmut, Paris, Bibliothèque nationale de France, MS lat. 16558. For more background on Christian sources see André Tuilier, "La condamnation du Talmud par les maîtres universitaires parisiens, ses causes et ses consequences politiques et idéologiques," in Le brûlement du Talmud, ed. Dahan and Nicolas, pp. 59-78.
} 
documented in both a Latin and a Hebrew report, the latter written most likely by the polemicist $R$. Joseph ben Nathan Official of Sens. ${ }^{74}$ Faced with the accusation that the talmudic Tractate of Idolatry was anti-Christian, R. Yehiel responded that the laws under discussion and any expressions hostile to gentiles do not refer to Christians. Rather, they refer specifically to ancient idolaters, whereas Christians belong to the category of Noahides, obliged to observe, together with the other laws of Noah, the prohibition of idolatry. The Christians, R. Yehiel argued apologetically, were thus excluded from any considerations of idolatry.

The Hebrew report opens with a discussion about the validity of the Talmud and continues with references to blasphemies against Jesus and his mother: Donin then takes up his accusations of anti-Christian hostility: “... and the heretic [Donin] raised his voice and said: you are imprudent to allow the bloodshed of gentiles (goyim), as [can be concluded from] your saying, 'The best of the gentiles, kill [him]." "75 $\mathrm{He}$ follows this with a list of restrictions regarding contacts with gentiles, asserting that they all prove Jewish hostility to Christians. R. Yehiel replies, first explaining that Donin had distorted the meaning of the word goyim, ${ }^{76}$ "Why do you open your mouth unjustly, when you do not know the meaning of the word goyim? This term includes good and bad [peoples]; it refers to good [peoples], as it is written (Psalms 117.1): 'praise the Lord all the peoples,' and to bad [peoples], as it is written (Psalms 9.18): 'all the peoples who are heedless of God." "77 Then he points out that the saying about killing the best of the gentiles refers to times of war, in particular to the persecution by the Egyptians, ${ }^{78}$ and not to contemporary European Christians, of whom he says, "This [is the] nation (uma) that we live among, and that protects us and keeps us alive; and we keep very strictly and by punishment the prohibition to harm them. . . ."79

A few lines later he refers to the restrictions concerning business negotiations during and before gentile holidays: "And I shall give you further proof: . . . you know that we keep the Torah, and many of us have been stoned, burned, drowned, killed, and strangled for its sake;.$\therefore$ we learn that it is prohibited to negotiate on the three days before the holidays of the gentiles, [but] go now to the street of the Jews and see how many of them [negotiate] even on the holiday itself." ${ }^{80} \mathrm{R}$. Yehiel refers then to the restrictions one by one, pointing out that contemporary practice

\footnotetext{
${ }^{74}$ Wikkuab Rabbenu Yehiel miparis miba ale hatosafot, ed. Ruben Margulies (Lvov, n.d.; repr. Jerusalem, 1975). For a comparison of the Hebrew report and the Latin sources see Friedrich Itzhak Baer, "A Critique of the Disputes of R. Yehiel of Paris and R. Moses ben Nahman" [in Hebrew], Tarbitz 2 (1931), 172-87; for an analysis of the Hebrew text from the point of view of its historical validity see Robert Chazan, "The Hebrew Report on the Trial of the Talmud: Information and Consolation," in Le brîlement du Talmud, ed. Dahan and Nicolas, pp. 79-93; Chazan tends to accept Joseph's authorship. Joseph ben Nathan left another polemical work, Sefer Yosef bameqane, which shares many stylistic characteristics with the Paris report; see Chazan, "Hebrew Report," p. 84, and also Galinsky, “Talmud Trial,” p. 48.

${ }^{75}$ Wikkuah rabbent Yehiel, ed. Margulies, p. 19.

${ }^{76}$ In the biblical context the term goyim means "peoples"; in medieval usage it normally refers to "gentiles."

77 Wikkuab rabbenu Yehiel, ed. Margulies, p. 20.

${ }^{78}$ For the original context see Mekbilta derabbi Ishmael, Beshallab 2, ed. Lauterbach, p. 201.

${ }^{79}$ Wikkuah rabbenu Yehicl, ed. Margulies, p. 21.

so Ibid.
} 
shows that they do not apply to Christians. Hostile restrictions, he argues, refer to the Egyptians and Canaanites of biblical times.

His argument then becomes more specific, as he makes a clear distinction between idolatrous gentiles and Christians. Donin cites the argument that the pollution caused by Eve's sin was removed from Israel on Mount Sinai but remained on all other nations. R. Yehiel replies that this applies only to those nations who did not accept the Torah, "but as to you, who accepted the Torah, and whose God does not contradict our Torah, and who did not add to it or reduce it, the pollution was removed from you, and the sayings of the sages of the Talmud do not apply to you." 81

Donin goes on to the question of heretics (minim) and the laws against heresy. Again R. Yehiel employs the strategy of correcting Donin's terminology: "The followers of Jesus are not heretics; rather those who believed in the Torah [given] on Mount Sinai but [reject] the Talmud [are considered heretics]." ${ }^{22}$ Here, of course; he expresses a personal polemic against Donin, the apostate. In this context $\mathrm{R}$. Yehiel is then asked by the bishops present if, in his opinion, the Christians will be worthy of salvation if they follow their own teachings. R. Yehiel is quite clear in this matter: "I tell you what will make you worthy of salvation: . . . if you keep the seven laws that were given to you, you will be redeemed." 83

Several questions arising from R. Yehiel's strategy affect the centuries-old perception that Christians are idolaters. R. Yehiel's argument, even if born out of a threatening necessity, was quite bold. One question is whether his statements are indebted to earlier halakhic considerations and the related observations that contemporary gentiles do not adhere to idolatry; more important, however, are the questions whether R. Yehiel's strategy had any far-reaching impact on any future perceptions of Christianity and whether it reflected a broader phenomenon of dealings with Christian accusations of the kind voiced in Paris. Solutions to those questions must come from historians; but to judge from the current state of research, it is possible to sketch a picture indicating that R. Yehiel's strategy was not developed in a vacuum and, most likely, did not disappear into oblivion without having an effect on Jewish perceptions of Christians.

First of all, it is plausible to assume, as Katz did, that earlier halakhic considerations with regard to business contacts did indeed influence R. Yehiel in developing his line of defense. ${ }^{84}$ If so, he developed the observation that the gentiles among whom medieval Jews lived did not adhere to idol worship into the declaration that the Jews count the Christians among the Noahides and that any hostile implications of the talmudic discussions refer only to pagan idolaters. R. Yehiel's arguments thus did not appear ad hoc; they were part of a process that forced the Jews - for both economic and apologetic reasons - to adjust their perception of Christians as idolaters.

As much as R. Yehiel's arguments relied on earlier considerations, Donin's accusation also grew out of a tradition. As Chazan argues, stereotypes of Jewish

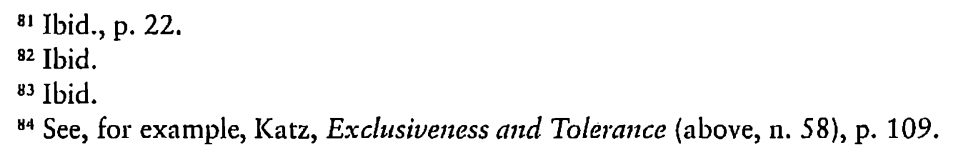


malevolence intensified during the second half of the twelfth century, and there is thus good reason to assume that Jews began to think of apologetical arguments prior to the events in Paris. ${ }^{85}$ More specifically, there may be evidence that Jews in southern Germany were also confronted with Donin's accusations and that this happened even prior to the actual trial. The point is important, as the earliest exemplars of Hebrew manuscript illumination appeared precisely in southern Germany, whereas in France signs of Jewish figural art do not occur before the second half of the twelfth century. It is possible that the knowledge of accusations such as Donin's, together with earlier stereotypes of the kind Chazan describes, led to thoughts similar to those expressed by R. Yehiel.

Donin's approach to Gregory IX was not the first time that he publicly advanced his opinion of the Jews. On Christmas Eve 1235 a ritual murder accusation was directed against the Jews of Fulda. ${ }^{86}$ In response Emperor Frederick II summoned a meeting of church officials and other authorities in Haguenau to investigate the accusation. No conclusive declaration was reached, and another meeting was held in July 1236 in Augsburg, which determined the accusations to be false. According to the Christian sources that document the Augsburg meeting, baptized Jews from France, England, and Spain were among those invited. ${ }^{87}$ As Israel Yuval observes, the Augsburg meeting may also be referred to in a Hebrew source, which indicates that Donin made an appearance there. ${ }^{88}$ The source, a polemical letter, was written between 1250 and 1260 by a Jewish scholar to a former student considering conversion, or perhaps already an apostate. ${ }^{89}$ Whereas most scholars identify the addressee as Pablo Christiani, who was involved in the Barcelona dispute in 1263 and the second Paris dispute in $1269,0^{\circ}$ there is no consensus as to the identity of the author. It was signed by R. Jacob ben Elijah or Elia, variously identified as Jacob de Lattes, a scholar from southern France who perhaps migrated to Valen-

${ }^{8 s}$ Chazan, Medieval Stereotypes (above,'n. 23), chaps. 2-3.

${ }^{86}$ For details see Gavin I. Langmuir, Touvard a Definition of Antisemitism (Berkeley, Calif., 1990), pp. 263-81.

${ }^{87}$ For more information and source material about these developments, other related ritual murder accusations, Frederick's subsequent declaration concerning the Jews' status as servi canerae, and Jewish messianic expectations that arose from this situation see Israel Jacob Yuval, "Two Nations in Your Womb": Perceptions of Jews and Christians in Late Antiquity and the Middle Ages, trans. Barbara Harshav and Jonathan Chipman (Berkeley, Calif., 2006), pp. 278-79.

${ }^{\text {s8 }}$ Ibid., pp. 278-84.

${ }^{89}$ R. Jacob ben Elijah, Iggeret R. Ya akov nivenetsia, ed. Joseph Kobak, in Jeschurrun: Zeitschrift fiir die Wissenschaft des Judenthums 6 (1868), 29-30.

${ }^{90}$ See Kobak in his remarks on the letter, ibid., addendum, pp. 208-9, where he acknowledges S. Z. H. Halberstamm as the private owner of one of the manuscripts of the letter. This view was later generally accepted; see Robert Chazan, "The Letter of R. Jacob ben Elijah to Friar Paul," Jewish History 6 (1992), 61, n. 7. For the Barcelona dispute see Hans-Georg von Mutius, Die christlichjiidische Zivangsdisputation zu Barcelona: Nach dem bebräischen Protokoll des Moses Nachmanides, Judentum und Umwelt 5 (Frankfurt am Main, 1982); and Robert Chazan, Barcelona and Beyond: The Disputation of 1263 and Its Aftermath (Berkeley, Calif., 1992). For the second Paris dispute see La deuxième controverse de Paris: Un chapitre dans la polémique entre chrétiens et juifs au moyen age, ed. Joseph Shatzmiller, Collection de la Revue des études juives 15 (Paris, 1994); Jeremy Cohen, "The Second Paris Dispute and Jewish-Christian Polemics in the Thirteenth Century" [in Hebrew], Tarbitz 68 (1999), 557-78, dating the dispute to the early 1270s; and Ursula Ragacs, Die zweite Talmuddisputation von Paris 1269, Judentum und Umwelt 71 (Frankfurt am Main, 2001). 
cia, or as a translator and scholar by that name who later lived in Venice. ${ }^{91}$ As his former teachex, R. Jacob warned Pablo Christiani of the consequences of apostasy and, among other arguments, referred to Donin's example. R. Jacob was referring to an appearance of Donin before "the king who is above all other kings," when Donin accused the Jews of ritual murder. The letter continues, stating that "the honorable king ... did not listen to his [Donin's] words." 92

Earlier scholarship linked the contents of this letter to the Fulda blood libel case, ${ }^{93}$ but Yuval argues that it specifically refers to the Augsburg convention, that the mention of "the king who is above all other kings" refers to none other than Emperor Frederick II, and that Donin was among the converted invitees from abroad. The letter does not contain an explicit list of the accusations probably made by Donin in Augsburg. His assertions were rejected, the accusations said to be false, and Donin decided to change his strategy. Refuted by the emperor, he approached, Yuval suggests, the emperor's adversary, Pope Gregory IX. ${ }^{94}$ What can be'gathered regarding the Fulda blood libel case, the Augsburg convention, and R. Jacob's letter is that Donin voiced ritual murder accusations before communicating them to the pope and that these accusations were first made in Germany. We do not get much enlightenment from R. Jacob's brief report, but one can speculate that Donin attempted to enhance his accusations of ritual murder by further details about talmudic anti-Christian hostility. Yuval suggests, for example, that the allegation that the Jews deem the best of the gentiles to be worthy of death had already been made by Donin in Augsburg_and would later be made in Paris - and that the more serious accusation of ritual murder partly relied on it. ${ }^{95}$ There can be little doubt that the Jews of southern Germany, or at least some of their representatives, anxiously followed the course of events in Augsburg; becoming aware of the accusations, they must have felt threatened and given some thought to ways of handling the advancing menace. How the Jews did handle it we see from the Paris Talmud trial.

Finally, the nature and presumed intention of the Hebrew report about the Paris trial also throw some light on the issues under discussion here. As some scholars assume, the report was not meant as a legal protocol but, rather, was written for Jews to guide them in coping with similar accusations when they found themselves required to defend themselves and their faith. ${ }^{96}$ Given the intensifying of antiJewish stereotypes since the middle of the twelfth century, there is good reason to

\footnotetext{
${ }^{91}$ On the author of the letter see Jacob Mann, "Une source de l'histoire juive au XIIIe siècle: La lettre polémique de Jacob b. Elie à Pablo Christiani," Revue des études juives 82 (1926), 363-77; Kenneth R. Stow, "Jacob of Venice and the Jewish Settlement in Venice in the Thirteenth Century," in Community and Culture: Essays in Jewish Studies in Honor of the Ninetieth Anniversary of the Foundation of Graetz College, 1895-1985, ed. Nahum M. Waldman (Philadelphia, 1987), pp. 221-32; Joseph Shatzmiller, "Jacob ben Elie, traducteur multilingue à Venise à la fin du XIIIe siècle," Micrologus 9 (2001), 195-202; and Chazan, "The Letter of R. Jacob ben Elijah."

${ }^{22}$ Iggeret, ed. Kobak, pp. 29-30.

${ }^{93}$ Grayzel, The Church and the Jews (above, n. 73), pp. 339-40; Joseph Shatzmiller, "Did the Apostate Nicholas Donin Promulgate the Accusation of Ritual Murder?" [in Hebrew], Mekblarim betoldot am Israel ve 'erets Israel 4 (1978), 173-82.

${ }^{94}$ See Yuval, Tivo Nations, pp. 278-84.

${ }^{95}$ Ibid., p. 281, n. 69.

${ }^{96}$ Chazan, "Hebrew Report" (above, n. 74), p. 90.
} 
believe that counterarguments were formulated and guidance occasionally given in oral form already prior to the events of 1240 in Paris. If so, R. Yehiel's publicly pronounced argumentation may not have been the result of a spontaneous impulse but rather part of an ongoing process, a line of thought that reflected not only the strategy of one scholar at a specific time and place but a more widespread strategy. In any event, the probable character of the protocol as polemical guideline shows that R. Yehiel's strategy was considered as a recommendation to other Jews.

The question of whether R. Yehiel's strategy did indeed reflect an intrinsic change in perception, if it indeed had any far-reaching effects on the Jewish perception of Christianity, is far more difficult to answer. R. Yehiel's argument was aimed at the ears of Christians, and its context is the Jewish-Christian debate. The question is, thus, whether it had an impact on the inner-Jewish discourse. The fact that medieval Jews had by now observed that Christians were not idolaters in the biblical or the talmudic sense does not mean that from then on they perceived them naturally and fully as monotheists. In the inner-Jewish discourse of Jewishespecially Ashkenazi-scholarship, Christians, as a matter of fact, were not referred to as Noahides. The notion of the Sons of Noah does appear in the sources; partial proselytes to Judaism belong to the category. Rashi, for example, made a clear distinction between those who observe the seven laws and those who adhere to idolatry. ${ }^{97} \mathrm{~A}$ similar distinction was made about two hundred years later in Catalonia by R. Moses ben Nahman (Nahmanides, d. 1270). ${ }^{98}$ Neither of those statements says anything explicit about the Christians.

Various Jewish texts continued to refer to Christian religious practice as idolatrous. In fact, the arguments described above led to a somewhat ambiguous and ambivalent view of Christians. ${ }^{99}$ This becomes clear, for example, when one reads R. Moses of Coucy's dealings with the laws against idolatry in his Sefer mitsvot gadol, a text written, scholars believe, under the influence- of the traumatic events in Paris. ${ }^{100}$ In fact, R. Moses was supposed to be present at the trial, although it may be understood from the texts that he did not appear. ${ }^{101}$ On the one hand, he seems to refer to Christians clearly and repeatedly as idol worshipers. ${ }^{102}$ On the other, it is not always entirely clear whether his references to gentiles as idolaters are theoretical-academic discussions based on talmudic sources and, if so, whether they are applicable to contemporary circumstances. The following text seems to describe Christian religious practice, but nothing in it refers explicitly to Christians, and, theoretically, it could mean pagan idolaters: "Regarding chalices that the gentile had rendered defective and nullified and that were [then] bought by a

\footnotetext{
97 Rashi on Babylonian Talmud, Yebamot 48b.

${ }^{98}$ Nahmanides, Hidushe haramban, masekhet makot, ed. Moshe Hershler (Jerusalem, 1970), p. 9a.

"See in this respect the discussion in Halbertal and Margalit, Idolatry (above, n. 31).

${ }^{100}$ Jeremy R. Woolf, "Some Polemical Emphases in the Sefer miswot gadol of Rabbi Moses of Coucy," Jewish Quarterly Review 89 (1998), 81-100; Galinsky, “Talmud Trial” (above, n. 71). These papers do not deal with explicit anti-Christian polemics in the Sefer mitsvot gadol but rather with the various methods $\mathrm{R}$. Moses recommends for the defense of the Talmud as such.

101 Woolf, "Polemical Emphases," p. 83, n. 10.

${ }^{102}$ See also Ephraim E. Urbach, The Tosafists: Their History, Their Work, Their Method [in Hebrew] (Jerusalem, 1954), p. 474, who points out that R. Moses, although sharing other scholars' opinion, presents this view with particular sharpness.
} 
Jew: it is prohibited to sell them to a gentile as the priest will use them for prayers of idolatry.... [This applies] also to books found worthy of idolatry. It is forbidden to sell them to gentiles because the priest reads them and sings from them and praises idolatry. It is even forbidden to sell them to a gentile who is not a priest, as the gentile will certainly sell them or give them to a priest." 103 The mention of chalices and books used for singing can certainly be associated with the Christian service; yet "Christians" are not mentioned explicitly, and the term priest (komer) can apply also to pagan practice. ${ }^{104}$ When it comes to business negotiation, $\mathrm{R}$. Moses adopted, as I have noted, the by-then common view and presented the Christians as gentiles "who are not really idolaters." 105

Neither R. Yehiel's assertion that the Christians are Noahides nor the argument that western Christians, at least, do not adhere to idol worship nor any other possible change of perception of Christianity had a positive effect on the Christian approach to the Jews. Nor did these shifts and arguments lead to any easing in the overall atmosphere of persecution. Therefore they did not relieve Jewish anxiety in any way or lessen the levels of aversion or hostility toward Christians resulting from the anti-Jewish policy spreading in central Europe. The only outcome was a slight shift in the Jews' attitude to their environment, a shift that had a practical basis, of either an economic or an apologetic nature, and left the Jews with an ambivalent perception of Christianity.

\section{SEPHARAD:}

\section{Nations Restricted by the Ways of Religion}

In Germany the belief that Christians were idolaters dominated-as shown above-before the thirteenth century. Similarly Maimonides, educated in Islamic Spain and active in North Africa, made a clear distinction between Christians and Muslims and left no room for doubt that he considered Christianity an idolatrous religion: "It is forbidden to drink the wine of a partial proselyte who accepted the seven laws, as we have explained; but it is permitted for [one's economic] benefit. One may put wine in his care, but one may not deposit [it] with him [as a pledge]. The same applies to all gentiles who do not worship idols, such as the Ismaelites; it is forbidden to drink their wine, but it is permitted for [one's economic] benefit; this is what the Geonim taught us; but as to the Christians who do worship idols: their wine is prohibited for profit." 106

A few decades later, in the middle of the thirteenth century, in the Crown of Aragon, Nahmanides was still drawing a parallel between the idolatrous Canaan-

${ }^{103}$ Sefer mitsvot gadol, p. 10a.

104 Below, pp. 102-5, I discuss the idea of R. Menahem Hame'iri of Perpignan, who referred to Christians as monotheists. The same R. Menahem, however, discussed at length the late-antique talmudic regulations regarding idol worship, applicable-according to his own concept of toleranceonly to pagan circumstances.

${ }^{105}$ Above, p. 94. This ambivalence was observed and discussed by Urbach, Tosafists, p. 475.

${ }^{106}$ Mishne Torah, Sefer hakedushah, Hilkhot ma akhalot assurot 11.7. In some editions the word "Christians" is omitted because of censorship; this citation is taken from Kappah's edition (above, $n$. 19), p. 281, which is based on a Yemenite manuscript; in n. 10 Kappah observes that "Christians" is omitted from most printed editions but appears in most manuscripts. 
ites and the Christians: "It appears to me that the Canaanites, who were engrossed in idolatry, used to make in all temples of their gods an altar on which to bring sacrifices, [and they] erected a large stone at the entrance of the temple for the priests to stand upon and planted a tree outside it to point the way for those who come there, and the Christians still do so to this day." ${ }^{107}$ Elsewhere Nahmanides explained that healing practices carried out in the name of Jesus are idolatrous healing practices. ${ }^{108}$

As in central Europe, this view probably prevented the development of figurative art during the eleventh, twelfth, and thirteenth centuries. ${ }^{109}$ It seems reasonable to suppose that this view, together with high levels of acculturation to Islamic culture in certain circles of the Jewish population, was the reason why Jewish book art in Spain was strictly aniconic for decades and why figurative art appeared only at the turn of the fourteenth century. ${ }^{110}$

Around 1300, however; R. Menahem Hame'iri of Perpignan (1240-1316), a philosopher and halakhist of the Maimonidean tradition, composed a commentary on the Talmud, entitled Beth habebira. In the section commenting on the Tractate of Idolatry he discussed at length the notion that Christians are not to be considered idolaters. He went far beyond the distinction made by earlier halakhists between the gentiles of antiquity, who were true idolaters, and contemporary gentiles, who do not adhere to idolatry, and introduced a new differentiation between "nations [of our time] that are restricted by the ways of religion" and the nations of the mishnaic and talmudic period, who were not restricted by the ways of religion. "11 Modern scholars speak about "the tolerance of Hame iri" and are concerned with the question of whether his views were influenced by earlier halakhic considerations of the Tosafists, by Jewish apologias of the type $\mathrm{R}$.

107 Nahmanides, Perushe hatorah, on Deuteronomy 16.22, ed. Charles B. Chavel, 2 (Jerusalem, 1960), p. 420. My translation is based on Nahmanides, Commentary on the Torah, trans. Charles B. Chavel, 5 (New York 1976), p. 198. Chavel's translation does not read "the Christians" but "they," meaning the Caananites. Chavel's Hebrew edition has "the Christians" with a footnote referring to various manuscript readings and corrections due to censorship.

${ }^{10}$ Nahmanides, Hidushe haramban, masekbet avodab zarah, ed. Hershler, p. 27a.

${ }^{109}$ According to Bland, however, the Ashkenazic view of Christians as idolaters was shared by southern French, but not by Sephardic, scholars; in his discussion of Benjamin of Tudela's travelogue (Artless Jetv [above, n. 22], pp. 138-39), Bland points out that Benjamin did not refer to Christian sites as sites of idolatry; he also argues that the commentaries of Abraham ibn Ezra, although written while he lived in Christian environments, "avoid condemning it [Christianity] for being idolatrous" (p. 115). Bland also mentions Judah Halevi in his discussion, asserting that Halevi did not refer to Christians as idolatrous, but he struggles with the interpretation of Halevi's sayings with regard to Christianity (pp. 132-33, esp. n. 86). Bland's conclusion in this matter is thus based on evidence from silence.

${ }^{110}$ Katrin Kogman-Appel, "Hebrew Manuscript Painting in Late Medieval Spain: Signs of a Culture in Transition," Art Bulletin 84 (2002), 247-72.

II' For example, R. Menahem Hame iri, Bet habebira al masekbet avodab zarah, ed. Abraham Sofer (Jerusalem, 1971), pp. 46, 59, and elsewhere. In the English wording I follow Gerald Blidstein, "Maimonides and Me'iri on the Legitimacy of Non-Judaic Religion," in Scholars and Scholarship: The Interaction between Judaism and Other Cultures, ed. Leo Landman (New York, 1990), p. 33. 
Yehiel employed in Paris, ${ }^{112}$ or by the atmosphere of Sephardic rationalist philosophy. Whatever the circumstances may have been, Hame'iri's discussion appears neither in a polemical-apologetical context nor as a by-product of establishing halakhic regulations for Jewish-Christian relations in specific economic situations. Rather, it appears in a context of both halakhic and moral-ethical considerations, and it is therefore better founded and more elaborately discussed.

The first to examine Hame 'iri's attitude to Christians in some depth was Katz, in 1952, arguing that the halakhic aspect of Hame 'iri's view was not entirely new but was based on earlier halakhic considerations. ${ }^{113}$ What Katz considered innovative, however, was the application of social and moral aspects to the concept. If Hame'iri's notion was grounded also on social or ethical considerations, it would mean that he did not simply rely on earlier halakhic discourse, since the references of medieval halakhists to Christians as idolaters or nonidolaters were, as already noted, ambivalent. Katz saw in Hame'iri's discussion a major change in the Jewish perception of Christians, beyond the necessity to adapt the Halakhah, and he considered the consequences also from a sociological point of view. Whereas the sayings of the Tosafists developed in a merely practical context and did not lead to a basic change of perception, Hame 'iri's tolerance grew out of the zeitgeist, the atmosphere prevailing among contemporary rationalist philosophers. Katz described Hame 'iri's discussion as the result of a gradual process leading to a dramatic change in the status of Christians in Jewish eyes. Moshe Halbertal argued that Hame iri's perception of restricted nations was influenced by the view that there are civilized people who live according to laws, whereas there are others at the margins of human society. In these views Hame'iri was influenced by common medieval perceptions. ${ }^{114}$ In contrast to Ashkenaz, where the observation that Christians do not adhere to idolatry had created a great deal of ambivalence, Hame'iri's view was apt to lead to more significant and far-reaching changes.

Ephraim Urbach, on the other hand, argued that Hame 'iri's discussion was not much more than a continuation of the halakhic method of the Tosafists. According to Urbach, the Tosafists, in their efforts to adapt the Halakhah to the contemporary practice of interactions with Christians, were responsible for the change in the perception of Christian practices. A viewpoint similar to Hame iri's, Urbach asserted, cannot be found in the writings of any other philosopher. ${ }^{115} \mathrm{Ta}$-Shma,

112 In 1263 a religious disputation took place in Barcelona (see above, p. 98); the disputants were Nahmanides and the abovementioned Pablo Christiani. This dispute was of a different character from the Paris trial and was concerned with religious beliefs, such as the Messiah and the virgin birth, and ways to prove or to refute them. Accusations of anti-Christian hostility, such as those made by Donin and refuted by R. Yehiel, were not discussed. The same is true for the 1269 Paris dispute (see above, p. 98).

${ }^{113}$ Jacob Katz, "Religious Tolerance in the Halakhic and Philosophical Method of R. Menahem Hame "iri" [in Hebrew], Zion 17 (1952), 15-30, and Exclusiveness and Tolerance (above, n. 58), chap. 10.

114 Halbertal, Rabbi Menaben Hame iri (above, n. 27), p. 108. See also David Berger, "Christians, Gentiles, and the Talmud: A Fourteenth-Century Jewish Response to the Attack on Rabbinic Judaism," in Religionsgespräche in Mittelalter; ed. Lewis and Niewöhner (above, n. 72), p. 117.

115 Ephraim E. Urbach, "R. Menahem Hame'iri's 'The Method of Tolerance': Its Roots and Its Limits" [in Hebrew], in Studies in the History of Jewish Society in the Middle Ages and the Modem Period Dedicated to Professor Jacob Katz on His Seventy-Fifth Birthday by Students and Colleagues [in Hebrew], ed. Immanuel Etkes and Joseph Shalmon (Jerusalem, 1980), pp. 36-37. 
finally, saw in Hame 'iri's view an entirely new way of thinking, but still only in a purely halakhic context. ${ }^{116}$ In a recent exhaustive study on Hame 'iri's worldview, Halbertal revisits the issue of tolerance and, faced with the earlier controversy, tends to follow Katz. ${ }^{17}$ In his analysis of Hame 'iri's concept he distinguishes between halakhic issues that regulate contacts with gentiles, on the one hand, and rights and duties in a legal sense that apply to Christians as "a nation restricted by the ways of religion," on the other. ${ }^{118}$

Looking at some of Hame iri's comments on halakhic issues, one cannot help detecting echoes of the earlier Tosafist method. At one point, for example, he says, "And we already explained that these issues [i.e., the talmudic restrictions] were all said at the time when the gentiles adhered to idol worship, but now idolatry has ceased at all places." 119 There can be no doubt, however, that the notion of nations restricted by the ways of religion led Hame 'iri to a tolerant perception of Christians that goes far beyond any halakhic considerations of the Tosafists. Hame'iri discussed various issues, analyzed in detail by Halbertal, that make it clear that his standpoint was indeed one of tolerance and not merely one of economic necessity. ${ }^{120}$

On the matter of images Hame'iri commented on the talmudic restrictions and discussions at length. He expounded in great detail the various distinctions between convex and concave images, objects intended for idolatry and those made for the sake of decoration only, objects produced by Jews and those made by gentiles, and many other matters. Most of this discussion is merely theoretical, and at one point he remarked, "I trust that now one can permit [with regard to] these issues that idolatry no longer exists and the religions have changed." 121

There remains, of course, the question whether Hame iri's approach was an isolated view and how influential it may have been. Katz believed that it was not

116 Ta-Shma, "Their Holidays," p. 209. Katz replied to both Urbach and Ta-Shma in 1981, "More on the Religious Tolerance of Menacliem Hame "iri" [in Hebrew], Zion 46 (1981), 243-46. On Hame' iri's considerations and doubts that are visible through his writings on this matter see Jacob [Gerald] Blidstein, "R. Menahem Me'iri's Attitude to Gentiles: Between Apologetics and Internalization" [in Hebrew], Zion 51 (1986), 153-66, revisiting the question of how much Hame "iri is indebted to former halakhic thought or to what degree he is innovative; on Hame'iri's legitimization of Christian worship see Blidstein, "Maimonides and Me'iri."

${ }^{17}$ Halbertal, Rabbi Menabem Hame iri, pp. 80-82, who argues against Urbach that the Tosafists never went so far as to see Christianity as a nonidolatrous religion. Rather, he interprets the saying that medieval gentiles do not adhere to idolatry in the sense that Christians do not properly "adhere to their oun religion" (my emphasis); he does not quote any of the texts literally but paraphrases them according to this interpretation. For Halbertal there is thus no ambivalence in the attitude of the Tosafists to Christians, as they scrupulously avoid referring to Christianity as a nonidolatrous religion. My differentiation between Rashi's earlier observation that contemporary gentiles are not skilled in idolatry and the later statements that they do not adhere to idolatry would make no difference from Halbertal's point of view.

${ }^{118}$ Halbertal, Rabbi Menabem Hame iri, pp. 80-108.

119 Hame iri, Bet habehira, Avodab zara, ed. Sofer, p. 28.

${ }^{120}$ Halbertal, Rabbi Menahem Hame iri, pp. 86-108. See, for example, the issue of cursing when passing houses of idolatry, which according to Hame'iri does not apply to churches, and other decisions that would even facilitate social friendship. This contradicts Katz's observation that Hame iri restricts social proximity; see below, p. 105.

${ }^{121}$ Hame 'iri, Bet habehira, Avodab zara, ed. Sofer, p. 152. 
an isolated one but was based on the education Hame iri had received from his teachers in a philosophical, rationalist environment. ${ }^{122}$ As David Berger has shown, Hame 'iri's argumentation and his distinction between the gentiles of antiquity and the Christians of the Middle Ages were followed around 1370 by R. Moses Hakohen of Tordesillas. R. Moses was placed in the position of defending the Talmud, and he used both the Tosafist halakhic considerations with regard to Christians and Hame iri's arguments. ${ }^{123}$

It was during Hame'iri's lifetime that Jews in Spain began to use figurative art in religious books. As mentioned earlier, the Haggadah that is now MS Or. 2737 of the British Library was produced in Castile around 1290, and the Golden Haggadah (Fig. 3) was produced in Barcelona c. 1320, four years after Hame 'iri's death. In circumstances differing from those of central Europe, it seems that in Spain, too, or rather in Spain in particular, and with far-reaching consequences, the shift in the Jewish perception of Christians was the influential factor in the development of Jewish figurative art. This shift made Jewish figurative art possible; moreover, it enabled the borrowing of Christian motifs, models, and symbols, a method pursued in Spain much more assiduously than elsewhere. The coming to grips with Christian art is much more complex in Spain than anywhere else.

As in Germany, this shift in attitude did not create a friendlier environment. It did not encourage more social proximity. As Katz observed, Hame'iri's tolerance was not based on a wish for social proximity. ${ }^{124}$ Jews were not saved from fearing Christian persecution and experiencing anti-Christian feelings as a result. In Spain all these developments occurred more slowly than in Germany; as Hame'iri made quite clear from the outset, the fact that Christians should not be considered idolaters did not mean that Jews should befriend them. ${ }^{125}$

\section{CONCLUSION}

Whereas the regulation of business negotiations and the legitimization of a common practice against a halakhic background were matters seriously discussed by medieval rabbinic scholars, the question of figural painting as such was mentioned only marginally. Contacts with gentiles had firmly established halakhic grounds, but the question of Jewish figural art was not a halakhic priority. As long as an object was two-dimensional, it was permitted by most late-antique rabbinic authorities. This was true for the late-antique period, for the early Middle Ages, and for the thirteenth century. Yet despite this basic halakhic attitude to artistic representation, figural art was common from the third to the sixth centuries, was interrupted around 550, and reappeared suddenly in the 1230s during a period

122 Katz, "Religious Tolerance," p. 29, n. 95.

${ }^{123}$ Berger, "Christians, Gentiles, and the Talmud," pp. 115-30. Of some relevance is also the fact, that, according to Katz, modern halakhists of the seventeenth and eighteenth centuries, an age of emancipation, saw themselves as followers of Hame'iri, even though they had no access to the text. Katz also argued that these modern halakhists were convinced that Hame'iri's view was actually based on Rashi's and the Tosafists' observation that contemporary gentiles are not skilled in or adhering to idolatry; see Katz, “Rabbi Menahem Hame iri," p. 15.

${ }^{124} \mathrm{Katz}$, "Rabbi Menahem Hame iri," p. 29.

${ }^{125} \mathrm{Katz}$, Exclusiveness and Tolerance, pp. 127-28. 
when Jewish-Christian relations had reached a particularly low point. After a period of almost seven hundred years of avoidance of figural art, the sudden adoption of a form of cultural expression that was identified for hundreds of years with the religious practice of the "Other," which over the centuries had become increasingly hostile, is thus an intriguing cultural shift. There is certainly nothing in the history of interpretation of the Second Commandment during the thirteenth century that could account for a cultural change of this dimension. This paper has sought to understand this change, not in terms of halakhic approaches toward images, but as symptomatic of certain developments in the social and cultural fabric of thirteenth-century Jewish and Christian societies and the interactions between them. What had changed by the 1230s-when the Munich Rashi commentary (Fig. 1) and the Ambrosiana Bible (Fig. 2) were produced-was not the theoretical halakhic basis but rather the Jewish perception of Christianity, which hitherto had been considered an idolatrous form of worship. This change in perception had economic, social, and apologetic, rather than halakhic, roots.

What began as the occasional observation that western gentiles were no longer "skilled in idolatry" and that therefore some of the restrictions regarding contacts with them could be eased developed gradually into the view that contemporary gentiles did not "adhere to idolatry." When R. Yehiel of Paris had to defend the Talmud in 1240, he employed a strategy that perhaps was indebted to these halakhic considerations about contemporary gentiles, and he explained that Jews refer to Christians as Noahides. By the end of the thirteenth century, R. Menahem Hame'iri in Perpignan referred to the Christians as a nation that, like the Jews, is restricted by the ways of religion, and on the basis of that notion he developed an entirely new concept of tolerance. These rabbinic sayings come from different social and cultural backgrounds and have economic, apologetic, or philosophical roots. They mark the gradual changes in the perceptions of Christianity in the Jewish mind, leading first to a great deal of ambivalence and then gradually undermining the firm perception that Christians were idolaters.

It is not for me to decide in what,way these developments are related. Their temporal coincidence with the appearance of Jewish figural art, however, strongly suggests that these changes in the perception of Christians as idolaters made Jewish figural art possible. ${ }^{126}$ The sources are silent about the exact circumstances in which figural art appeared, and none of them brings this development into direct correlation with any considerations of the halakhic attitude to Jewish-Christian economic interactions. But the temporal coincidence of the appearance of Ashkenazic figural art (Figs. 1 and 2) with discussions of Christians who do not adhere to idolatry and with the development of R. Yehiel's apologetic strategy is striking.

\footnotetext{
126 Some observations by Bland seem to support these assumptions. Bland describes the Ashkenazic perception of Christians as idolatrous and implies that during the thirteenth century a change can be observed. Although "Christian images and monuments" in late-medieval Jewish scholarship embodied "alien Christian spirituality," and were thus condemned, they were not described as idolatrous objects: "occasionally, the Jews were aware that the direct objects of Christian worship were made without idolatrously worshiping the wood and image itself." The northern French polemicist R. Joseph Kimhi, for example, was aware that Christians as much as Jews were commanded against idolatry, and $\mathrm{R}$. Joseph ben Nathan discusses idolatry with his Christian disputant in a "subtle and dialectical" way. See Artless Jew, pp. 142-43 with references to the relevant texts.
} 
Similarly the temporal coincidence of the pictorial cycles in Sephardic Haggadot (Fig. 3) with Hame iri's reflections is remarkable. In Ashkenaz the observation that Christians may, after all, not be idolaters created ambivalence; in contrast, Hame'iri's views were firm, secure, and presented in great depth. Ashkenazic figural art, even though appearing as early as the 1230s, developed more slowly than Jewish art in Spain and with some hesitation; in most cases it was less inspired by Christian imagery than was Sephardic art. Sephardic figural art, on the other hand, developed unrestrainedly once Hame iri had made his arguments; it interacted with Christian art in numerous ways and dealt with its messages creatively and polemically.

Katrin Kogman-Appel is Associate Professor in the Department of the Arts at Ben-Gurion University of the Negev (e-mail: katrin@woobling.org). 